\title{
PRODUÇÃO DE Pleurotus sajor-caju EM BAGAÇO DE CANA- DE-AÇÚCAR LAVADO E O USO DE ADITIVOS VISANDO SUA CONSERVAÇÃO "IN NATURA"
}

\author{
EVELISE MONCAIO MODA
}

\begin{abstract}
Dissertação apresentada à Escola Superior de Agricultura "Luiz de Queiroz", Universidade de São Paulo, para obtenção do título de Mestre em Ciências, Área de Concentração: Ciência e Tecnologia de Alimentos.
\end{abstract}

P I R A C I C A B A

Estado de São Paulo - Brasil

Abril - 2003 


\title{
PRODUÇÃO DE Pleurotus sajor-caju EM BAGAÇO DE CANA- DE-AÇÚCAR LAVADO E O USO DE ADITIVOS VISANDO SUA CONSERVAÇÃO "IN NATURA"
}

\author{
EVELISE MONCAIO MODA
}

Engenheiro Agrônomo

Orientador: Profa. Dra. MARTA HELENA FILLET SPOTO

\begin{abstract}
Dissertação apresentada à Escola Superior de Agricultura "Luiz de Queiroz", Universidade de São Paulo, para obtenção do título de Mestre em Ciências, Área de Concentração: Ciência e Tecnologia de Alimentos.
\end{abstract}

P I R A C I C A B A

Estado de São Paulo - Brasil

Abril - 2003 


\section{Dados Internacionais de Catalogação na Publicação (CIP) DIVSÃO DE BIBLIOTECA E DOCUMENTACÃO - ESALQ/USP}

Moda, Evelise Moncaio

Produção de Pleurotus sajor-caju em bagaço de cana-de-açúcar lava do e o uso de aditivos visando sua conservação "in natura" / Evelise Moncaio Moda. - - Piracicaba, 2003.

84 p. : il.

Dissertação (mestrado) - - Escola Superior de Agric ultura Luiz de Queiroz, 2003.

Bibliografia.

1. Aditivos a limentares 2. Cogumelo comestível 3. Conservação de a liment 4. Qualidade dos a limentos I. Título

CDD 641.658

"Permitida a cópia total ou parcial deste documento, desde que citada a fonte - O autor" 


\section{DEDICO}

Aos meus pais, Edson e Ivanira e aos meus sogros Ari (in memoriam) e Elvira; aos meus enteados Marcius, Marcus e minha filha Caroline pelo carinho e compreensão constantes; especialmente ao meu marido Ariovaldo, pelo amor, dedicação e trabalho em todo o momento. 


\section{AGRADECIMENTOS}

Ao Prof. Dr. Silvio Sandoval Zocchi, do Departamento de Matemática e Estatística (ESALQ/USP) pela orientação e análise estatítica do trabalho, e principalmente, pela grande amizade e apoio oferecidos continuamente através dos anos.

Ao Dr. Caio Nogueira Cardoso (in memorian) pelo fornecimento do inóculo utilizado no trabalho, pela amizade de muitos anos e pelo incentivo à pesquisa, sempre.

Ao Prof. Dr. Jorge Horii, do Departamento de Agroindústria, Alimentos e Nutrição (ESALQ/USP), pelo acolhimento, amizade e orientação durante todo o curso.

A Dra. Rachel Domarco do Departamento de Entomologia e Irradiação de Alimentos do Centro de Energia Nuclear na Agricultura (CENA/USP), pela concessão do laboratório para a realização das análises de coloração e firmeza e pela orientação e correção do trabalho.

A Técnica Especializada Clarice Matraia, do Departamento de Entomologia e Irradiação de Alimentos do CENA/USP pela simpatia constante e ajuda na realização das análises. 
Aos funcionários do Departamento de Agroindústria, Alimentos e Nutrição, setor Açúcar e Álcool (destilaria), especialmente ao sr. Pedro Rossini Filho pelo apoio e ajuda durante todo o trabalho.

Aos funcionários do Departamento de Agroindústria, Alimentos e Nutrição, setor Açúcar e Álcool, Rosemary Leonessa da Silva, Vana Maria Caseri e Sylvino Luiz Torrezan pela amizade e apoio constantes.

Ao estagiário Giuliano Gabrielli, pela amizade, boa vontade e dedicação nas fases de implementação e realização do projeto.

A Coordenação de Aperfeiçoamento de Pessoal de Nível Superior (CAPES), pela concessão de bolsa de estudos.

A secretária do curso de Pós-Graduação em Tecnologia de Alimentos, Regina Lúcia de Mello Lourenço, pela simpatia e orientação acadêmica durante o curso.

A bibliotecária Ligiana Clemente do Carmo pela correção do material e auxílio bibliográfico.

A todos aqueles que contribuíram de alguma forma para o êxito deste trabalho. 


\section{SUMÁRIO}

Página

LISTA DE FIGURAS........................................................................ viii

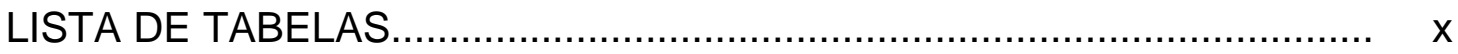

RESUMO

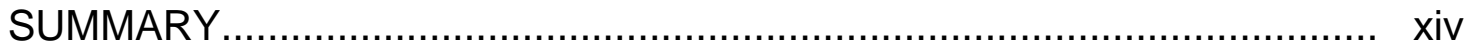

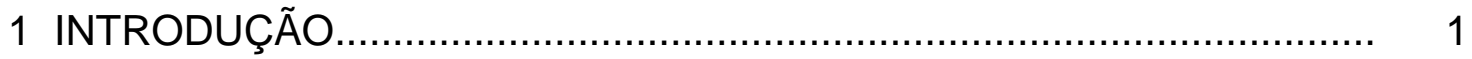

2 REVISÃO DE LITERATURA.......................................................... 5

2.1 Classificação....................................................................... 5

2.2 Método tradicional de produção de cogumelos................................... 8

2.3 Métodos alternativos de produção de cogumelos................................. 11

2.4 Suplementação dos substratos..................................................... 13

2.5 Eficiência biológica (EB)........................................................... 15

2.6 Fixação de nitrogênio............................................................... 18

2.7 Conservação pós-colheita com o uso de soluções................................ 19

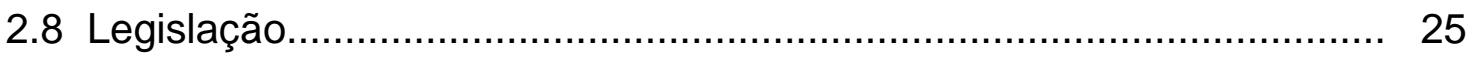

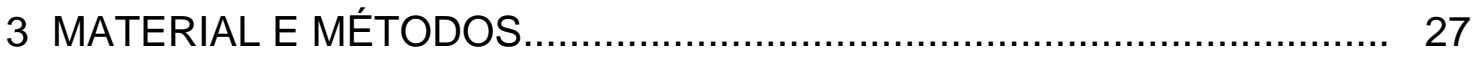

3.1 Produção dos cogumelos............................................................. 27

3.1.1 Produção do inóculo.................................................................. 27

3.1.2 Produção do "spawn" ou "semente-inóculo"..................................... 28

3.1.3 Produção do substrato de cultivo.................................................. 29

3.1.3.1 Produção do substrato de cultivo lavado...................................... 29

3.1.3.2 Produção do substrato de cultivo suplementado........................... 32

3.2 Conservação dos cogumelos........................................................ 35

3.2.1 Coleta dos cogumelos............................................................... 35 
3.2.2 Preparo das soluções............................................................. 35

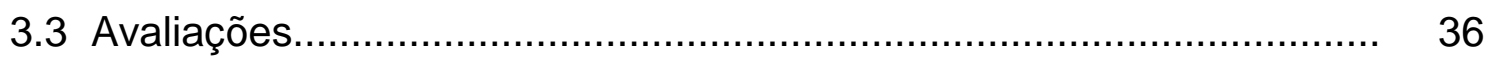

3.3.1 Produção dos cogumelos............................................................ 36

3.3.2 Análises físicas dos cogumelos.............................................. 37

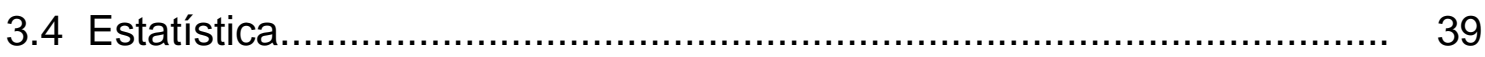

3.4.1 Produção dos cogumelos............................................................ 39

3.4.1.1 Produção do substrato de cultivo lavado....................................... 39

3.4.1.2 Produção do substrato de cultivo suplementado............................ 39

3.4.2 Conservação dos cogumelos........................................................ 39

4 RESULTADOS E DISCUSSÃO............................................................ 40

4.1 Produção dos cogumelos............................................................... 40

4.1.1 Produção do substrato de cultivo lavado........................................ 40

4.1.1.1 Eficiência biológica (EB) e eficiência biológica média (EBM)........... 40

4.1.1.2 Contaminações.................................................................. 46

4.1.2 Produção do substrato de cultivo suplementado............................... 48

4.1.2.1 Eficiência biológica (EB) e eficiência biológica média (EBM)........... 48

4.1.2.2 Contaminações.................................................................. 51

4.2 Análises físicas dos cogumelos......................................................... 53

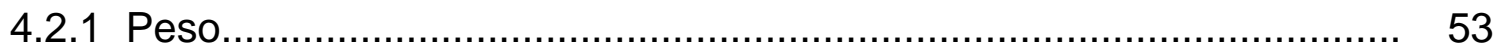

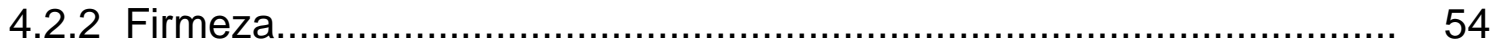

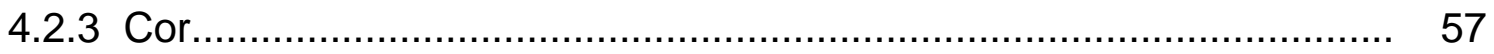

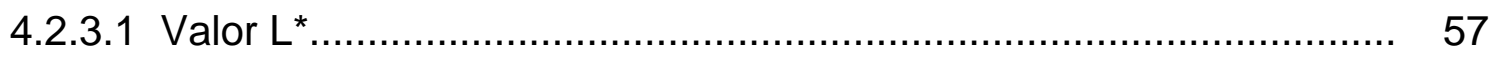

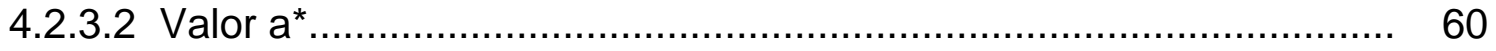

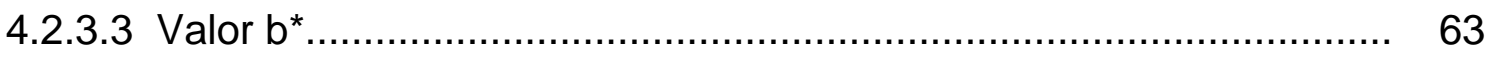

4.2.4 Considerações gerais..................................................................... 64

5 CONCLUSÕES...................................................................... 72

REFERÊNCIAS BIBLIOGRÁFICAS.................................................... 73 


\section{LISTA DE FIGURAS}

Página

1 Pleurotus sajor-caju (Fr.) Singer..................................................... 7

2 Aparelho utilizado na lavagem do bagaço de cana-de-açúcar.................... 30

3 Fluxograma de produção do substrato de cultivo lavado........................... 31

4 Fluxograma de produção do substrato de cultivo suplementado................ 34

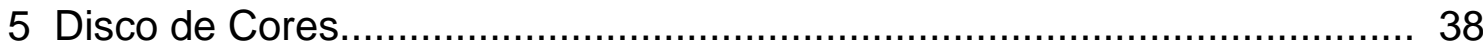

6 Cogumelos Pleurotus sajor-caju em substrato lavado e suplementado com solução nutritiva........................................................................ 49

7 Peso das bandejas durante o período de armazenamento........................ 54

8 Firmeza dos cogumelos durante o período de armazenamento.................. 56

9 Luminosidade $\left(L^{\star}\right)$ dos cogumelos durante o período de armazenamento.. 59

10 Valor $\mathrm{a}^{\star}$ dos cogumelos durante o período de armazenamento.............. 62

11 Valor b* dos cogumelos durante o período de armazenamento............... 65 
12 Distribuição dos tratamentos durante o período de armazenamento, em relação aos valores $a^{*}$ e $b^{\star}$

13 Distribuição das repetições durante o período de armazenamento, em relação aos valores $a^{\star} e b^{\star}$......

14 Coloração no dia 0 , representada pelos valores $a^{*} e b^{\star}$, para o controle $(\square)$, para o tratamento com solução de ácido cítrico (O), para o tratamento com solução de peróxido de hidrogênio $(\Delta)$ e para água destilada (

15 Coloração no dia 5, representada pelos valores $a^{\star}$ e b*, para o controle $(\square)$, para o tratamento com solução de ácido cítrico (O), para o tratamento com solução de peróxido de hidrogênio $(\Delta)$ e para água destilada

16 Coloração no dia 10 , representada pelos valores $a^{\star}$ e b*, para 0 controle $(\square)$, para o tratamento com solução de ácido cítrico (O), para o tratamento com solução de peróxido de hidrogênio $(\Delta)$ e para água destilada ( $\square$ ) 


\section{LISTA DE TABELAS}

Página

1 Composição da solução nutritiva em $200 \mathrm{~mL}$ de água destilada.

2 Produção, contaminação e EB dos substratos lavado e pasteurizado........

3 EBM entre os tratamentos lavado e pasteurizado

4 Análise química do bagaço de cana-de-açúcar lavado sem suplementação e do cogumelo Pleurotus sajor-caju coletado deste substrato...

5 Produção, contaminação e EB dos substratos lavado, lavado com suplementação orgânica e lavado com suplementação mineral.

6 EBM dos substratos lavado, lavado com suplementação orgânica e lavado com suplementação mineral.

7 Garantia mínima em nutrientes da solução nutritiva.................................. 52

8 Firmeza dos cogumelos tratados com ácido cítrico, peróxido de hidrogênio, água destilada e controle durante o período de armazenamento 
9 Luminosidade $\left(\mathrm{L}^{\star}\right)$ dos cogumelos tratados com ácido cítrico, peróxido de hidrogênio,água destilada e controle durante o período de

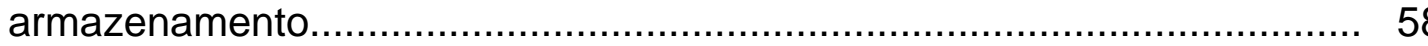

10 Valor $\mathrm{a}^{\star}$ dos cogumelos tratados com ácido cítrico, peróxido de hidrogênio, água destilada e controle durante o período de

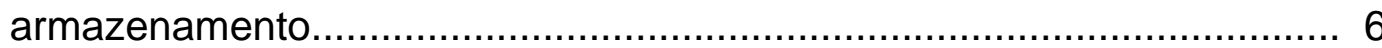

11 Valor b* dos cogumelos tratados com ácido cítrico, peróxido de hidrogênio, água destilada e controle durante o período de

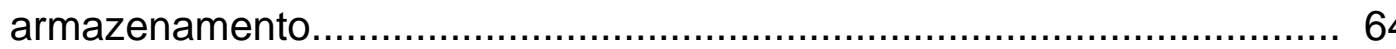




\title{
PRODUÇÃO DE Pleurotus sajor-caju EM BAGAÇO DE CANA-DE-AÇÚCAR LAVADO E O USO DE ADITIVOS VISANDO SUA CONSERVAÇÃO "IN NATURA"
}

\author{
Autor: EVELISE MONCAIO MODA \\ Orientador: Profa. Dra. MARTA HELENA FILLET SPOTO
}

\section{RESUMO}

Tradicionalmente, o cultivo do cogumelo comestível Pleurotus sajorcaju ou "hiratake" é realizado em diferentes resíduos agrícolas, precedido pelos processos de compostagem e pasteurização. Apresenta uma delicada consistência sendo comercializado preferencialmente "in natura", com tempo de vida útil de 3 a 7 dias, dependendo das condições de armazenamento. Os objetivos do presente trabalho foram: eliminar a fase de pasteurização do substrato através da lavagem do bagaço da cana-de-açúcar, com posterior suplementação visando um aumento na produtividade e prolongar o tempo de comercialização do cogumelo fresco através da sua imersão em diferentes soluções. Na primeira parte do trabalho, os colmos da cana-de-açúcar passaram por moenda para a extração do caldo, sendo em seguida desfibrados. Um lote foi pasteurizado em água a $80^{\circ} \mathrm{C}$ durante 2 horas; outro lote foi lavado em água corrente à temperatura ambiente em um aparelho adaptado, durante uma hora. Foram drenados e acondicionados em sacos de polietileno com a "semente-inóculo" (5\% sobre a matéria úmida). A lavagem simples no aparelho foi utilizada para o experimento com suplementação; um 
lote recebeu suplementação com quirera de milho (suplementação orgânica); outro foi suplementado com solução nutritiva (suplementação mineral) e o controle não foi suplementado; em ambos os experimentos foram avaliadas a eficiência biológica e a contaminação do substrato. Na segunda parte do trabalho, os cogumelos colhidos foram imersos em diferentes soluções (ácido cítrico, peróxido de hidrogênio e água destilada) durante 2 minutos, foram drenados, acondicionados em bandejas de poliestireno e mantidos sob refrigeração $\left(4^{\circ} \mathrm{C}\right)$ durante 10 dias; foram avaliadas a coloração, textura, aparência e o peso. A lavagem simples do bagaço de cana-de-açúcar mostrouse eficiente no controle dos microrganismos competidores durante as fases de colonização do substrato e produção dos cogumelos. A suplementação mineral do bagaço lavado com solução nutritiva resultou em eficiência biológica média (EBM) de 30,03\%, sendo superior ao controle, com EBM de 26,62\%; o menor desempenho foi obtido com a utilização da suplementação orgânica no bagaço lavado, apresentando EBM de 15,66\%. Em relação à conservação do cogumelo fresco, ocorreram perdas de textura e peso, bem como o amarelecimento dos cogumelos em todos os tratamentos, não apresentando diferença entre as soluções citadas e o controle no final do período de avaliação. Portanto, os processos de imersão nas soluções de ácido cítrico, peróxido de hidrogênio e água destilada não apresentaram resultados satisfatórios para a conservação dos cogumelos frescos. 


\title{
PRODUCTION of Pleurotus sajor-caju IN WASHED SUGAR CANE BAGASSE AND THE FRESH MUSHROOMS'SHELF LIFE EVALUATION BY TREATMENT WITH DIFERENT SOLUTIONS
}

\author{
Author: EVELISE MONCAIO MODA \\ Adviser: Profa. Dra. MARTA HELENA FILLET SPOTO
}

\section{SUMMARY}

Traditionally, the cultivation of edible mushroom Pleurotus sajor-caju or "hiratake" has been carried out on different composted and pasteurized agricultural residues. They are usually sold in natura and according to the storage conditions the mushrooms'shelf life varies from 3 to 7 days. The objectives of this study were to investigate the traditional processes of compostage and pasteurization in substitution by washed and supplemented (mineral or organic) sugar cane bagasse and evaluate the increase of fresh mushrooms'shelf life by immersion into different solutions. In the first experiment, the fresh sugar cane bagasse was washed in fresh water and packed in ethylene bag added with the spawn; the suplementation of washed sugar cane bagasse was mineral (with the nutritive solution) or organic (with the corn gritz). The biological efficiency and the contamination of the substrate were analysed. After harvest, the mushrooms were immersed into different solutions for 2 minutes, dryed, packed in trays and kept under refrigeration $\left(4^{\circ} \mathrm{C}\right)$ for 10 days. Coloration, texture, weight and global aspect of the mushrooms were evaluated in this period of storage. The washed bagasse was efficient to inhibit 
the growth of competitive microorganisms during the spawning and production of the mushrooms. The supplementation with nutritive solution presented the best biological efficiency media (BEM), 30,03\% while with the control was $26,62 \%$. The corn gritz presented the worst performance, with a BEM of $15,66 \%$. The yellowish of mushrooms occurred and their texture and weight decreased. The global aspect of the immersed mushrooms had no difference compared to the control not immersed. This process of immersion into different solutions did not extend the shelf life of fresh mushrooms. 


\section{INTRODUÇÃO}

Os fungos vêm sendo utilizados pela humanidade há milhares de anos, tanto para fins alimentícios como para fins medicinais e cerimoniais. Participam desde a produção de cervejas, vinhos, molhos de soja, queijos, até produção de penicilina, ácidos orgânicos e outros produtos.

Cerca de 2000 espécies de cogumelos pertencentes a pelo menos 30 gêneros são consideradas comestíveis, mas apenas 20 são cultivadas comercialmente e somente 5 ou 6 espécies são produzidas em escala comercial, destacando-se: Agaricus bisporus (champignon-de-Paris), Lentinula edodes (shiitake) e Pleurotus sp. (hiratake ou shimeji), segundo Pascholati et al. (1998).

O cultivo de cogumelos tem uma longa tradição no sudoeste asiático, datando de 600 a.c., com o cultivo de Auricularia auricularia, ou orelha-de-pau, enquanto que o cultivo de Agaricus bisporus é desenvolvido desde o século XVII, na França (Kües \& Liu, 2000). O champignon-de-Paris é o cogumelo mais popular em todo o Ocidente, enquanto que no Japão, China e Coréia o shiitake tem uma longa tradição de cultivo, onde são produzidos em troncos de árvores, como carvalhos e atualmente eucaliptos (Subramanian, 1995).

De acordo com Ferreira (1998), são produzidos mundialmente 4 milhões de toneladas de cogumelos por ano, sendo os principais produtores: Estados Unidos, França, Alemanha, Holanda, China e Japão, e os principais consumidores: Alemanha, Holanda, Japão e China. No Brasil, o consumo restringe-se a 5 mil toneladas por ano, com dados estimados somente pelo 
consumo do produto fresco nas principais capitais. Estes dados estão subestimados, em virtude da falta de um controle efetivo sobre a quantidade comercializada nas demais cidades brasileiras e também por não avaliar a quantidade de cogumelos desidratados ou em conservas consumidos.

Segundo a Companhia de Entrepostos e Armazéns Gerais de São Paulo (CEAGESP, 1998) foram comercializados no estado de São Paulo $15.615 \mathrm{~kg}$ de cogumelos frescos, vendidos em bandejas de $250 \mathrm{~g}$ cada. A maior porcentagem de venda concentrou-se na grande São Paulo, com a absorção de $80 \%$ do total comercializado. Este fato deve-se à grande concentração de colônias japonesas, coreanas, chinesas, italianas e alemãs residentes na cidade de São Paulo e consumidoras de várias espécies de cogumelos.

A expansão da cultura de cogumelos comestíveis depende de estudos visando maior produtividade, controle de qualidade, aproveitamento da matéria orgânica disponível, produção a baixo custo e exportação. Em termos comerciais, o cogumelo apresenta uma das maiores taxas de retorno por unidade de área, podendo gerar um lucro de até $150 \%$ sobre o capital investido ao final do período produtivo. Esta porcentagem pode variar em função do cogumelo cultivado e da época do ano, em razão dos períodos de safra e entressafra de algumas espécies.

A produção anual mundial de cana-de-açúcar é estimada em 775 milhões de toneladas. Após a extração do açúcar, que gira em torno de 62 milhões de toneladas, o restante é bagaço, de acordo com Permana et al. (2000). Segundo Ferreira (1998), a abundante oferta deste resíduo agrícola faz do Brasil um país com grande potencial produtivo; se fossem utilizados $25 \%$ a $30 \%$ do bagaço produzido pelas usinas sucroalcooleiras brasileiras ( 25 milhões de toneladas), a oferta mundial de cogumelos poderia ser dobrada.

Várias são as vantagens do cultivo do Pleurotus sp.: facilidade de manejo e produção, ocupando pouco tempo e espaço na localidade; utilização de matérias-prima como palhas, capins e bagaço, abundantes e baratas; não 
requer climatização, podendo ser cultivado em qualquer região do Brasil; tem resistência a pragas e doenças e seu crescimento é bastante rápido, permitindo um rápido retorno do investimento (Rajarathnam, 1992; Poppe, 2000).

Além destas vantagens, após a colheita dos cogumelos o substrato residual, com alta digestibilidade e rico em nutrientes, poderá ser utilizado na alimentação de ruminantes e suínos, podendo também ser aproveitado como fertilizante ou na produção de biogás, de acordo com Mansur et al. (1992) e Buswell \& Chang (1993).

O cultivo de cogumelos representa um eficiente caminho na reciclagem de resíduos, convertendo-os em alimento com conteúdo protéico de até $40 \%$ em base de peso seco e grande valor nutricional e medicinal; desta forma, justifica-se sua produção em países em desenvolvimento (Rajarathnam \& Bano, 1989).

A principal dificuldade no cultivo do Pleurotus sajor-caju é a etapa de desinfestação do substrato, anterior à inoculação. Os processos tradicionais de cultivo envolvem as fases de compostagem do material e sua pasteurização, com o intuito de homogeneizar o substrato de cultivo e reduzir a população de microrganismos competidores, respectivamente (Winzentier et al., 1996). Estas fases aumentam os custos produtivos, dificultando o acesso para muitos potenciais produtores. Desta forma, a introdução de uma nova metodologia na produção de substrato, excluindo-se a fase de compostagem e pasteurização, torna-se interessante à medida que possibilita o acesso de um maior número de produtores ao cultivo do Pleurotus sp., com diminuição dos custos produtivos e do tempo de produção.

Os cogumelos Pleurotus sajor-caju permanecem aceitáveis para o consumo até 36 horas após a colheita, mantidos em temperaturas entre $21^{\circ} \mathrm{C}$ e $25^{\circ} \mathrm{C}$. São pouco aproveitados como conserva, devido ao tamanho avantajado que dificulta o processamento. São geralmente comercializados "in natura" ou industrializados em pedaços, como ingredientes de sopas, patês e recheios. Desse modo, a baixa temperatura é importante na sua preservação, pois 
retarda a sua atividade metabólica. Nardim (1999) citou que o cogumelo resfriado não resistiu à temperaturas entre $0^{\circ} \mathrm{C}$ e $5^{\circ} \mathrm{C}$ por mais de dez dias, sendo que o Pleurotus sp. degradou-se mais lentamente que o Agaricus bisporus ou o Lentinula edodes.

O uso de soluções, associadas ou não ao resfriamento, tem sido muito utilizado na conservação de Agaricus bisporus fresco em diversos países, com bons resultados. O ácido cítrico é usualmente adotado no tratamento de cogumelos frescos inteiros ou fatiados, atuando como acidulante e conservante; o peróxido de hidrogênio em pequenas concentrações é utilizado como conservante.

Outras substâncias foram avaliadas, como o hipoclorito de cálcio (Kuyper et al., 1993), o cloreto de cálcio (Roy et al., 1995a) e o sorbitol (Roy et al., 1995b) para melhorar a qualidade e aumentar a vida útil de cogumelos frescos.

O objetivo deste trabalho foi avaliar a possibilidade de desenvolvimento do micélio do cogumelo comestível Pleurotus sajor-caju em bagaço de cana-de-açúcar lavado, investigando também a necessidade de suplementação deste substrato, buscando-se um incremento na produção e qualidade dos cogumelos.

Outro propósito desse estudo foi o aumento da conservação do produto "in natura", através da imersão dos cogumelos Pleurotus sajor-caju em diferentes soluções, comparando-os quanto à qualidade e durabilidade como produto fresco. 


\section{REVISÃO DE LITERATURA}

\subsection{Classificação}

Os fungos possuem habilidade para desenvolverem-se em qualquer substância orgânica, fazendo uso de substratos variados (Singer \& Harris, 1987). As fontes de carbono como polissacarídeos, lignina, glicose, manose, frutose, óleos e ácidos orgânicos são importantes fornecedoras de energia para a atividade metabólica dos cogumelos e constituem a base para a síntese de proteínas e substâncias de reserva, resultando em aproximadamente 50\% do peso da matéria seca dos corpos de frutificação em carbono, de acordo com Zanetti \& Ranal (1997).

Desta forma, desempenham importante papel de decompositores na natureza, assimilando os elementos e transformando-os em substâncias mais simples, permitindo a reciclagem dos nutrientes. Os fungos podem ser saprófitas, colonizando matéria orgânica em decomposição ou parasitas, quando suas hifas colonizam matéria orgânica viva, sobre ou dentro do hospedeiro. Também podem desenvolver processos simbióticos com outros seres vivos, como nos caso das trufas, que aparecem sempre em associação micorrízica com carvalhos (Bononi et al., 1995).

Até o momento, todos os cogumelos cultivados comercialmente no Brasil são saprófitas, da classe dos Basidiomycetes: champignon-de-Paris (Agaricus bisporus), shiitake (Lentinula edodes), shimeji ou hiratake (Pleurotus sp.) e cogumelo-do-sol (Agaricus blazei), de acordo com Bononi \& Trufem (1985). 
Todos os fungos são decompositores de matéria orgânica, mas somente os pertencentes à classe dos Basidiomycetes e alguns Ascomycetes produzem cogumelos verdadeiros. A produção do cogumelo é o ápice do ciclo vital desta espécie; também pode ser denominado de fruto, corpo de frutificação, carpóforo ou basidiocarpo. Na maturação dos cogumelos, o píleo se abre, as lamelas são expostas e ocorre a disseminação dos esporos. Estes são sexuais, haplóides, resultado do processo de divisão meiótica dentro do basidiocarpo. Os esporos germinados dão origem às hifas, que formam o micélio primário; a união de micélios primários compatíveis gera um micélio dicariótico ou micélio secundário, responsável pela formação dos primórdios, que darão origem aos cogumelos (Chang \& Miles, 1984; Rajarathnam, 1987).

Também chamado de cogumelo gigante, caetetuba, hiratake, shimeji e oystermushroom, o cogumelo Pleurotus sp. é grande, com píleo de 6 a $10 \mathrm{~cm}$, formando uma "pétala" ou "leque" e nascendo em cachos (Ferreira, 1998). estipe é lateral ou nulo, apresentando lâminas decurrentes; em geral o píleo não é facilmente separável do estipe (Perala Santolaria, 1964). De acordo com Zadrazil (1980), o Pleurotus sajor-caju é um cogumelo com grande habilidade saprofítica de colonização e pode colonizar substratos esterilizados, pasteurizados $\left(60-90^{\circ} \mathrm{C}\right)$ e fermentados.

Segundo Alexopoulos \& Blackwell (1995), a classificação do cogumelo em estudo é: 
Reino Fungi

Divisão Basidiomycota

Classe Basidiomycetes

Subclasse Holobasidiomycetidae

Ordem Agaricales

Família Tricholomataceae

Gênero Pleurotus

Espécie Pleurotus sajor-caju (Fr.) Singer

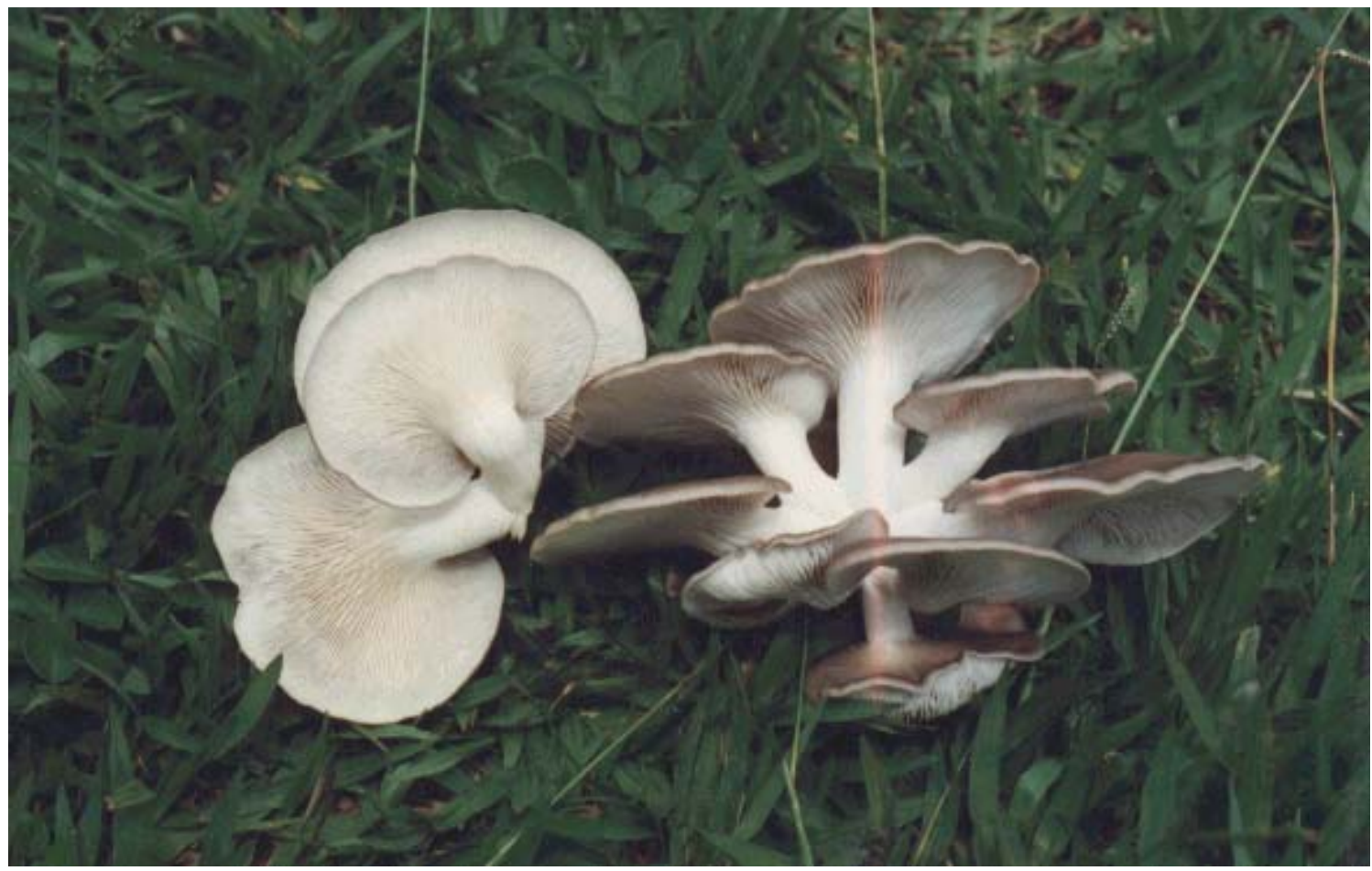

Figura 1 - Pleurotus sajor-caju (Fr.) Singer. 
De acordo com Stamets (1993), a produção do Pleurotus sajor-caju pode ser dividida em três etapas, com necessidades distintas. A primeira etapa é denominada de "corrida do micélio", onde o fungo coloniza o substrato já preparado anteriormente; necessita de temperatura ambiente de $24-29^{\circ} \mathrm{C}$ e umidade relativa de $90-100 \%$, com duração de 8 a 14 dias. A segunda etapa ocorre durante a formação do primórdio; necessita de temperatura ambiente de $15-27^{\circ} \mathrm{C}$ e umidade relativa de $90-100 \%$, com duração de 3 a 5 dias. A terceira etapa refere-se ao desenvolvimento do fruto; necessita de temperatura ambiente de $18-27^{\circ} \mathrm{C}$ e umidade relativa de $85-90 \%$, com duração de 3 a 5 dias.

\subsection{Método tradicional de produção de cogumelos}

Os cogumelos comestíveis dos gêneros Agaricus e Pleurotus são cultivados no Brasil principalmente através do uso da compostagem dos materiais utilizados na produção do substrato e sua posterior pasteurização sob vapor fluente. Estes processos podem ser utilizados em diversos tipos de resíduos agroindustriais, como bagaço de cana-de-açúcar, palha de trigo, palha da folha de bananeira, palha de milho, entre outros. A compostagem do material é realizada dentro do período de 15 a 20 dias; são acrescentados ao material celulósico resíduos agrícolas ou adubos minerais que contenham uma boa porcentagem de nitrogênio, como farelo de soja, farelo de trigo, farinha de ossos e nitrato de amônia, na proporção de 10:1, respectivamente. O composto é acrescido de calcário dolomítico (1\% sobre o peso úmido do substrato) e disposto em pilhas com 1,80 $\mathrm{m}$ de altura, comprimento e largura variáveis. A umidade do material deve estar em torno de $70 \%$ e a pilha deve ser revolvida a cada 4 dias para promover a aeração adequada e homogeneidade do substrato. Durante esta fase, ocorre o desenvolvimento de microrganismos que iniciam a degradação do material, disponibilizando nutrientes para o cultivo do cogumelo. Finalizada a compostagem, é feita a pasteurização deste composto, com o objetivo de destruir parcialmente a população de microrganismos 
competidores, reduzindo a possibilidade de contaminações após a inoculação do micélio do cogumelo a ser cultivado. Normalmente, a pasteurização é realizada em túneis com entrada de vapor injetado, onde o substrato compostado permanece por 2 a 3 dias sob temperaturas que variam de 55 a $80^{\circ} \mathrm{C}$. Após este processo, o substrato é inoculado com a semente e acondicionado em sacos plásticos ou bandejas, seguindo para uma estufa de produção, onde será mantido sob temperatura e umidade controladas durante aproximadamente 50 dias, com o final do período produtivo. Apresenta picos de produção, chamados de fluxos produtivos, com intervalos entre fluxos de 5-8 dias. Em cultivos comerciais, os substratos são descartados após o terceiro fluxo, devido à redução da produtividade.

O bagaço de cana-de-açúcar é um importante resíduo da agricultura no Brasil, sendo amplamente empregado na produção de compostos fertilizantes e na produção de cogumelos, principalmente do gênero Pleurotus. Contém mais de $70 \%$ de celulose na matéria seca, porém sua digestibilidade é menor que $10 \%$, devido à alta porcentagem de lignina presente no material. Uma alternativa para a quebra da lignina é o uso de fungos basidiomicetos, como os cogumelos do gênero Pleurotus, que podem degradar o complexo lignocelulósico da cana-de-açúcar, de acordo com Ortega et al. (1992).

Os materiais utilizados no preparo do substrato, assim como o tempo de compostagem e pasteurização apresentam variações conforme a literatura. Maziero et al. (1992) utilizaram bagaço de cana e farelo de arroz na produção de Pleurotus ostreatus var. "Flórida"; a compostagem do material foi realizada durante 48 horas e a pasteurização foi feita sob vapor fluente em túnel de pasteurização durante 24 horas a $59^{\circ} \mathrm{C}$, apresentando boa produtividade e baixa taxa de contaminação. Já Abe et al. (1992) utilizaram bagaço de cana suplementado com sulfato de amônia e superfosfato simples para a produção de Pleurotus ostreatus sob diferentes temperaturas de pasteurização. As temperaturas foram de $75^{\circ} \mathrm{C}$ durante 48 horas e $82-84^{\circ} \mathrm{C}$ durante 48 horas, sendo que o primeiro tratamento apresentou melhor resultado. 
Sturion \& Oetterer (1995) trabalharam com bagaço de cana, palha de trigo, palha da folha da bananeira e sabugo de milho na produção de várias espécies de Pleurotus, isolados ou misturados em diferentes proporções; estes materiais foram compostados e pasteurizados sob vapor fluente durante 1 hora a $90^{\circ} \mathrm{C}$ e foram acondicionados em sacos plásticos de polietileno, sendo depois transferidos para uma sala de cultivo. Os resultados encontrados, expressos em eficiência biológia, variaram de acordo com a mistura utilizada na preparação do substrato e com a espécie de cogumelo inoculada. Já Colauto \& Eira (1995) trabalharam com bagaço de cana e palha da cultura de feijão na produção de Pleurotus sajor-caju; a compostagem foi realizada durante 15 dias, com reviragem da pilha a cada 5 dias e manutenção da umidade do material em $75 \%$. A pasteurização deste composto foi realizada através da injeção de vapor a $75^{\circ} \mathrm{C}$ durante 4 horas, e o substrato foi disposto em bandejas paralelepipidais com diferentes profundidades ou foram acondicionados em sacos plásticos de polietileno, sendo conduzidos em estufa. O melhor resultado foi obtido nas camas paralelepipidais, com a maior produção concentrada no primeiro fluxo; nos sacos plásticos, a maior produção foi obtida no segundo e terceiro fluxos. Felinto (1999) utilizou bagaço de cana-de-açúcar e resíduos da cultura da mandioca para o cultivo de Pleurotus sajor-caju; o material foi compostado e pasteurizado com vapor à temperatura média de $70^{\circ} \mathrm{C}$, durante 2 dias. A produtividade do substrato, avaliada através da eficiência biológica, foi prejudicada devido a uma alta porcentagem de contaminação, principalmente durante o primeiro fluxo produtivo.

Pleurotus sajor-caju também foi produzido em substrato anteriormente utilizado na produção de Lentinula edodes (shiitake); analisando a composição fibrosa do substrato já utilizado, Royse (1992) observou que 85\% da hemicelulose, $44 \%$ da celulose e $77 \%$ da lignina originais não haviam sido utilizadas durante o período de produção do shiitake. Este substrato foi moído, adicionado de $12 \%$ de farelo de soja e $1 \%$ de carbonato de cálcio e foi pasteurizado novamente sob vapor fluente, a $85^{\circ} \mathrm{C}$ durante 24 horas, resultando 
em boa produtividade do cogumelo. A produção de Lentinula edodes em bagaço de cana misturado com bagaço de mandioca também foi testada por Beux \& Soccol (1996), com compostagem do material por 15 dias e pasteurização sob vapor fluente a $70^{\circ} \mathrm{C}$ durante 2 dias; a primeira colheita dos cogumelos ocorreu 65 dias após a inoculação, com bons resultados.

Para a produção de Agaricus bisporus em substrato à base de palha de trigo e esterco de cavalo, Bononi (1984) utilizou vapor injetado para a pasteurização do composto com temperaturas entre $58-60^{\circ} \mathrm{C}$ durante 48 horas e $48-50^{\circ} \mathrm{C}$ por mais 7 dias. Peil et al. (1995) utilizaram o processo de compostagem durante 21 dias, com seis reviragens e manutenção da umidade da pilha em 70\%. A pasteurização do composto para a produção de Agaricus bisporus foi testada a $60^{\circ} \mathrm{C}$, durante 6 a 8 horas e $45-55^{\circ} \mathrm{C}$, durante 4 dias, sendo que o segundo tratamento apresentou melhores resultados.

O tipo de substrato utilizado, assim como a espécie cultivada têm grande influência na composição química dos cogumelos, podendo ocorrer variações, principalmente em relação a qualidade proteica dos mesmos. Desta forma, a qualidade dos materiais a serem utilizados, suas características

químicas e físicas devem ser levadas em consideração na produção de cogumelos comestíveis.

\subsection{Métodos alternativos de produção de cogumelos}

Apesar da maioria dos produtores comerciais utilizarem os métodos tradicionais de compostagem e pasteurização para a produção de Pleurotus sp., outros processos têm sido avaliados em trabalhos de pesquisa. Os mais utilizados são a pasteurização do substrato em água quente $\left(80-100^{\circ} \mathrm{C}\right)$ e a esterilização do substrato em autoclaves.

Macaya-Lizano (1988) trabalhou com a mistura de palha de arroz (60\%), cedro amargo (20\%) e resíduo do beneficiamento do arroz (20\%) com suplementação de cama de frango ou farinha de algodão em diferentes 
proporções; os substratos foram autoclavados a $56,8 \mathrm{~kg}$ de pressão durante 20 segundos, com os melhores resultados obtidos no substrato sem suplementação. Zanetti \& Ranal (1996) trabalharam com a mistura de casca de algodão, resíduo de bainhas de folhas de guariroba (Syagrus oleracea), resíduos da industrialização do milho-doce e cana-de-açúcar triturada; os materiais foram autoclavados a 1 atmosfera durante 30 minutos, para a produção de Pleurotus ostreatus. A eficiência biológica e produtividade variaram em relação ao tipo de mistura utilizada na formulação do substrato de cultivo.

Avidos (1997) utilizou-se da técnica chinesa de produção de cogumelos comestíveis denominada Jun Cao para a produção de Pleurotus sajor-caju, onde determinadas espécies de gramíneas são utilizadas como substrato de cultivo e são suplementadas e autoclavadas a 1 atmosfera durante 20 minutos. Esta técnica possibilitou um aumento na produção de cogumelos comestíveis na China da ordem de $250 \%$ em quatro anos.

Pleurotus sp. foram produzidos com a utilização de diversos materiais, como palha de arroz, palha de trigo, palha de milho, bagaço de cana e resíduos de papel, através do processo de pasteurização do substrato em água quente. Os materiais foram triturados, misturados em diferentes proporções e mergulhados em água à temperatura ambiente por 12 horas para promover a hidratação do substrato; foram em seguida imersos em água a $100^{\circ} \mathrm{C}$ por 2 a 3 horas (Bahukhandi \& Munjal, 1989).

Balasubramanya \& Kathe (1996) cultivaram Pleurotus sajor-caju em palha de arroz ou palha de trigo, misturadas com resíduos do cultivo do algodão, através da pasteurização do substrato em água a $80^{\circ} \mathrm{C}$ durante 2 horas. Outro tratamento utilizado foi o uso da fermentação anaeróbica destes materiais em tubos de polietileno de $30 \mathrm{~cm}$ de altura contendo solução de Saccharomyces cerevisae. Os materiais triturados permaneceram 7 dias dentro dos tubos, com o objetivo de reduzir ou eliminar os microrganismos competidores durante a fase de produção do cogumelo através da acidificação do meio. Os resultados obtidos foram semelhantes em ambos os tratamentos, 
com boa produção de cogumelos e pequena taxa de contaminação; as espécies de microrganismos que mais apareceram após a pasteurização com água quente foram Trichoderma sp. e Penicillium sp.; nos materiais digeridos estes microrganismos não foram encontrados.

O cultivo através de fermentação submersa foi estudado por Gomez (1990), que utilizou bagaço de cana e levedura de destilaria como substrato para o desenvolvimento do micélio de Pleurotus ostreatus, obtendo desta forma um produto final rico em proteínas e carboidratos e com boa digestibilidade, baseado nos baixos teores finais de lignina encontrados. $O$ micélio obtido pode ser utilizado diretamento como alimento devido ao seu conteúdo proteico ou como aditivo em alimentos processados.

Solução com hidróxido de cálcio também pode ser utilizada como método alternativo para a pasteurização do substrato, com a inativação de fungos e bactérias através da elevação brusca do pH; o micélio do Pleurotus sp. tolera esta mudança melhor que os microrganismos competidores. O hipoclorito de sódio a 5,25\% em água também é utilizado para a imersão e pasteurização de substratos para a produção de Pleurotus sp., de acordo com Stamets (1993).

\subsection{Suplementação dos substratos}

A suplementação dos substratos para o cultivo de cogumelos é prática usual adotada pela grande maioria dos produtores. Normalmente são acrescentados ao material celulósico uma fonte de nitrogênio, podendo esta ser orgânica, através da utilização de resíduos agroindustriais ricos em nitrogênio, ou mineral, com o uso de adubos nitrogenados solúveis ou parcialmente solúveis em água.

Zadrazil (1980) verificou que a produção de Pleurotus sajor-caju e Pleurotus ostreatus aumentou em 50\% com a suplementação da palha de trigo com nitrato de amônia e acima de $300 \%$ com a suplementação com farelo de soja ou alfafa. O efeito da suplementação foi maior para Pleurouts sajor-caju 
que para Pleurotus ostreatus, sendo que a adição de pequenas quantidades de nitrato de amônia no substrato ocasionou o aumento da velocidade de decomposição da matéria orgânica. A adição de substâncias de rápida assimilação, como o farelo de soja ou alfafa, aumentaram a decomposição da matéria orgânica proporcionalmente à quantidade adicionada.

Pleurotus sajor-caju é um cogumelo apto a colonizar materiais com altos teores de lignina e baixos teores em nutrientes, como o bagaço de canade-açúcar. Suplementos nitrogenados minerais, como o nitrato de amônia e o nitrato de cálcio foram utilizados na produção dos cogumelos; porém a suplementação com material orgânico obteve melhores resultados, correlacionado o aumento de nitrogênio orgânico no substrato com o aumento da produção, de acordo com os trabalhos de Royse et al. (1991) e Permana et al. (2000). Mansur et al. (1992) suplementaram o bagaço de cana-de-açúcar com folhas de lírio aquático, obtendo bons resultados no cultivo de Pleurotus sp., devido à alta capacidade de retenção hídrica e níveis elevados em nitrogênio deste material.

No Brasil, é muito comum a utilização do bagaço de cana suplementado com farelo de trigo ou farelo de arroz e carbonato de cálcio para a produção de Pleurotus sp., como no trabalho de Maziero et al. (1992). A suplementação do bagaço de cana com $15 \%$ de feijão guandú também foi avaliada, aumentando a produção e a eficiência biológica de Pleurotus ostreatus var. "Flórida" (Zanetti \& Ranal, 1997).

No entanto, Macaya-Lizano (1988) verificou que a adição de suplemento nitrogenado, como cama de frango e farinha de algodão não resultou em aumento da produtividade de Pleurotus sp. e não diminuiu o período entre os picos produtivos; foi sugerido pelo autor ser o gênero Pleurotus essencialmente celulósico. Bisaria et al. (1997) também relataram que a suplementação orgânica ou mineral pode ser utilizada somente em pequenas quantidades, pois o excesso de nitrogênio pode inibir a síntese das enzimas degradadoras da lignina, e sendo a lignina um polímero recalcitrante, a 
degradabilidade do substrato pode decrescer. A atividade das enzimas lignolíticas pode ajudar a estimar a biomassa de Pleurotus sp. em substratos sólidos, porque elas são específicas para os fungos de "podridão branca" (Wiesche et al., 2000).

A adição de cloreto de cálcio na água de irrigação do substrato de

Pleurotus pulmonarius reduziu o tempo de corrida do micélio e aumentou a produção, resultando em maiores níveis de cálcio e aminoácido nos cogumelos. Já a adição de cloreto de manganês à água de irrigação provocou decréscimo na produção, além de propiciar um escurecimento dos cogumelos, de acordo com Chiu et al. (1998). Segundo Barden et al. (1990), a adição de cloreto de cálcio na água de irrigação causou o aumento da vida útil de Agaricus bisporus em 64\%, com redução do número de bactérias e do escurecimento superficial do píleo, embora a produção de cogumelos tenha sido reduzida em $16 \%$. A adição de hipoclorito de cálcio à água de irrigação na produção de Agaricus bisporus também reduziu significativamente a contagem microbiana nos cogumelos (Kuyper et al., 1993).

\subsection{Eficiência biológica (EB)}

A eficiência biológica (EB) representa a porcentagem de conversão do substrato seco em cogumelos frescos, obtida através de uma fórmula simples, originalmente desenvolvida pela indústria de Agaricus bisporus ou "champignon-de-Paris":

$\mathrm{EB} \%=$ peso fresco total dos cogumelos $/$ peso seco do substrato inicial $\times 100$

Em termos gerais, pode-se dizer que $1 \mathrm{~kg}$ de cogumelos frescos obtidos de $1 \mathrm{~kg}$ de substrato seco representa 100\% de EB. Considerando-se que o substrato tenha umidade aproximada de $75 \%$, e a maioria dos cogumelos tem uma umidade em torno de $90 \%$ após a colheita, 100\% de EB equivale ao crescimento de $1 \mathrm{~kg}$ de cogumelos frescos para cada $4 \mathrm{~kg}$ de substrato úmido, numa conversão de $25 \%$ do peso de massa do substrato em cogumelos 
frescos, ou $10 \%$ de conversão da massa seca do substrato em cogumelos secos. De acordo com Stamets (1993), o melhor meio para aumentar a eficiência biológica ou a produtividade seria simplesmente aumentar a porcentagem de inóculo ou "semente" do cogumelo no substrato de cultivo. No entanto, este procedimento é inviável na prática por motivos econômicos. A EB também depende do estado de maturação do cogumelo na época da colheita; a colheita de cogumelos jovens, ainda na fase de botão, reduz a EB devido à diminuição do tamanho e massa do fruto. A colheita de cogumelos maduros pode oferecer ao produtor a máxima $E B$, porém os frutos terão uma vida útil reduzida em comparação ao cogumelo jovem, diminuindo seu tempo de comercialização (Rajarathnam, 1998).

Vários autores utilizaram a EB como principal parâmetro de avaliação no cultivo de cogumelos; Chang et al. (1981) produziram Pleurotus sajor-caju em resíduos da cultura do algodão, com EB de 79,18\%, em 4 fluxos produtivos; Madan et al. (1987) obtiveram uma EB de $108 \%$ com a produção de Pleurotus sajor-caju em palha de trigo, enquanto que Bisaria et al. (1987) obtiveram uma EB de $78 \%$ para o mesmo cogumelo e substrato; Royse \& Schisler (1987) obtiveram $85 \%$ de EB para a produção de Pleurotus ostreatus em palha de trigo e espiga de milho e $73 \%$ de EB para a produção de Pleurotus sajor-caju no mesmo substrato de cultivo.

Sturion \& Oetterer (1995) obtiveram diferentes EB nos tratamentos avaliados na produção de Pleurotus sajor-caju: EB de 50,33\% em palha de bananeira; EB de 43,27\% em palha de trigo; EB de 48,29\% em palha de bananeira e bagaço de cana e EB de 19,15\% em palha de bananeira e sabugo de milho. Já Colauto \& Eira (1995) obtiveram resultados inferiores na produção de Pleurotus sajor-caju em blocos cilíndricos (EB de 39,9\%) em comparação à produção em bandejas paralelepipidais, com substrato a base de bagaço de cana e palha de feijão. Pleurotus sajor-caju produzidos em sacos de polietileno com substrato à base de palha de trigo obtiveram uma EB de $32,1 \%$ no trabalho de Dhanda et al. (1996), enquanto que Singh (2000) e Sangitrao (2000) 
obtiveram uma EB de $109,3 \%$ e 101,05\%, respectivamente, na produção de Pleurotus sajor-caju em palha de arroz e palha de trigo, correlacionando o aumento na produção com a degradação da celulose, hemicelulose e lignina do substrato.

A EB também pode estar relacionada com o grau de contaminação dos substratos; estes contaminantes estão implicitamente correlacionados com as boas práticas de higiene e associados a diversos vírus. A contaminação do substrato por microrganismos competidores pode reduzir drasticamente a produção de cogumelos ou até mesmo interrompê-la; as boas práticas de higiene contribuem de maneira definitiva na redução da contaminação dos substratos, promovendo um aumento na produtividade e lucro para o produtor.

No trabalho de Grogan et al. (2000) testou-se o efeito inibitório de seis microrganismos competidores na produção do primeiro fluxo de Agaricus bisporus; a inoculação de Trichoderma pseudokoningii no substrato de cultivo ocasionou um efeito inibitório de $8 \%$ na produção do cogumelo; para Acremonium murorum e Pythium oligandrum registrou-se um efeito inibitório de 18\%; para Trichoderma atroviride e Penicillium sp., registraram-se respectivamente $26 \%$ e $84 \%$ de efeito inibitório. A inoculação de Fusarium sp. não ocasionou a redução na produtividade do substrato.

Outro microrganismo importante na produção de cogumelos, principalmente em Pleurotus sp., é a bactéria Pseudomonas stutzeri. Durante o trabalho de Mallesha \& Shivappashetty (1988), esta bactéria ocasionou perdas significativas na produção de Pleurotus sajor-caju, variando de $27 \%$ a $61 \%$. Observou-se que os produtores com melhor tecnologia e higiene na produção tiveram menores taxas de infecção e maior produtividade, reforçando a idéia que correlaciona higiene e produção.

Wizentier et al. (1996) observaram em trabalho com bagaço de cana na produção de Pleurotus sajor-caju que o bagaço na saída das moendas a $58^{\circ} \mathrm{C}$ apresentou populações diversificadas de fungos e bactérias e em pequeno número. Esta diversidade sugeriu serem simples contaminantes e não 
microbiota residente. Já no bagaço mantido em estoque por 30 dias, a menor diversidade e a maior freqüência das populações sugeriram ter havido condições de crescimento e seleção de microrganismos neste ambiente, sendo microbiota residente.

\subsection{Fixação de nitrogênio}

Alguns autores observaram em seus trabalhos com cogumelos do gênero Pleurotus uma indicação de possível fixação de nitrogênio, quando foram comparados os teores em nitrogênio do substrato com os teores encontrados nos cogumelos, em geral superiores. Alguns autores também citaram o Pleurotus como um gênero essencialmente celulósico, uma vez que a suplementação do substrato com materiais nitrogenados acabou ocasionando redução na produtividade (Kurtzman, 1978; Macaya-Lizano, 1988 e Bisaria et al., 1989).

Ortega et al. (1992), com o cultivo de Pleurotus sp. em bagaço de cana suplementado, descreveram um incremento em nitrogênio nos cogumelos em relação a quantidade presente no substrato inicial somada à quantidade de nitrogênio presente no inóculo, indicando uma possível fixação deste elemento pelos cogumelos.

Patrabansh \& Madan (1997) observaram aumento da quantidade de nitrogênio no substrato após o cultivo de Pleurotus sajor-caju, indicando uma possível capacidade de fixação de nitrogênio por este fungo. Sturion \& Oetterer (1995) também verificaram este fato, com o aumento de nitrogênio no substrato residual, variando de $4 \%$ a $37 \%$ no cultivo de Pleurotus sp. em diferentes materiais, sugerindo a habilidade dessas espécies em fixar nitrogênio, ou então a presença de bactérias fixadoras associadas ao cogumelo. Entretanto, a presença do micélio do cogumelo no substrato pode ter contribuído para a obtenção destes valores, uma vez que a parede celular fúngica possui em sua composição um polissacarídeo, a quitina, que apresenta nitrogênio em sua 
estrutura, podendo superestimar a quantidade de nitrogênio no substrato residual.

Yara (2002) registrou em seu trabalho a presença de microrganismos presentes no interior do cogumelo Pleurotus sp.; as bactérias se desenvolveram em diversos meios de cultura e puderam ser observadas no interior de vacúolos, junto às hifas do micélio. A ausência de parede celular indicou a morfologia de microrganismos semelhantes a micoplasmas MLO (micoplasma like organisms) ou de bactérias em forma de L; o seqüenciamento de parte do gene ribossomal $16 \mathrm{~S}$ indicou que estas bactérias eram semelhantes à bactéria Burkholderia cepaci, podendo estar relacionada à fixação de nitrogênio nos cultivos de cogumelos do gênero Pleurotus.

\subsection{Conservação pós-colheita com o uso de soluções}

Os cogumelos Pleurotus sp. permanecem aceitáveis para o consumo "in natura" durante poucas horas após a colheita em temperaturas próximas a $25^{\circ} \mathrm{C}$. A preservação dos cogumelos nesta forma é importante para a redução da perda de nutrientes e aroma durante o processamento anterior à secagem; também estimula o consumo local do produto e a expansão para o mercado externo.

A fisiologia pós-colheita dos cogumelos é refletida pela composição química e atividade metabólica dos cogumelos frescos. Deste modo deve-se considerar o conteúdo de água, a taxa respiratória, a firmeza dos frutos, o grau de escurecimento, a atividade de proteases e aminoácidos livres e o desenvolvimento de aroma posterior à colheita (Bano \& Rajarathnam, 1988).

As enzimas polifenoloxidases (tirosinase), quando em presença de substratos fenólicos e oxigênio, catalizam a oxidação dos compostos fenólicos para quinonas, as quais são rapidamente condensadas, formando complexos pigmentos de coloração marrom - as melaninas. As enzimas tirosinase e catecolase são distinguidas por sua atividade em substratos específicos e são 
responsáveis pelo processo de escurecimento enzimático nos cogumelos. Eventualmente, a prevenção da ruptura dos tecidos ou a inativação das enzimas por calor ou sulfitação, assim como a redução do pH por meio de ácidos pode ajudar a reduzir o escurecimento enzimático dos cogumelos. A tirosinase é encontrada na maioria dos cogumelos; sua presença é sugerida nos tecidos reprodutivos, devido à toxidez gerada pela ação de oxidação promovida pela enzima, que é capaz de destruir microrganismos invasores (Burton, 1980). Flegg (1991) aponta a supressão do cobre, que faz parte da estrutura da tirosinase ou polifenoloxidase, como meio efetivo de melhorar a qualidade dos cogumelos, aumentando sua vida útil. A coenzima da tirosinase responsável pela degradação da tirosina é um complexo cúprico-proteico, de acordo com Moraes (1995). Qualquer substância que sequestre o cobre reduzirá a formação enzimática normal da melanina, diminuindo o escurecimento dos cogumelos.

Nardim (1999) relatou que o efeito causado pela polifenoloxidase em relação ao escurecimento enzimático foi menor em Pleurotus sp. que em Agaricus bisporus ou mesmo Lentinula edodes. Este fato deve-se à coloração do Pleurotus sp., que é naturalmente mais escura.

De acordo com Gormley (1975), a temperatura de armazenamento exerce grande influência no grau de deterioração de cogumelos. $O$ autor verificou em seu trabalho que o tempo de resfriamento para Agaricus bisporus e a temperatura utilizada influíram na manutenção da cor branca, fator importante na aceitação do produto pelo consumidor. A coloração branca de Agaricus bisporus é o mais importante aspecto de qualidade do produto "in natura". O melhor resultado foi obtido no resfriamento a $1^{\circ} \mathrm{C}$ durante 5 dias, para o cogumelo fresco. Em trabalho realizado por Tano et al. (1999) relatou-se que o ponto mais importante na manutenção da vida útil de cogumelos após a colheita foi a temperatura. Foram testadas diferentes temperaturas de armazenamento para Agaricus bisporus frescos; à temperatura de $20^{\circ} \mathrm{C}$ a qualidade dos cogumelos foi severamente afetada após o período de 12 dias, 
indicada pelo extensivo escurecimento, perda de firmeza e aumento de etanol em comparação com a testemunha, armazenada a $14^{\circ} \mathrm{C}$. Nardim (1999) observou em seu trabalho que de modo geral, o cogumelo resfriado não resistiu à temperatura entre $0^{\circ} \mathrm{C}$ e $5^{\circ} \mathrm{C}$ por mais de dez dias, variando em média, de $4 \mathrm{a}$ 7 dias. No entanto, observou também que o Pleurotus sp. degradou-se mais lentamente que o Agaricus bisporus ou o Lentinula edodes nas mesmas condições.

A sulfitação consiste em tratamento químico utilizado no processamento de frutas e hortaliças com a finalidade de inibir o escurecimento enzimático. O sulfito dissolvido na água forma o dióxido de enxofre, que é o componente ativo utilizado contra o escurecimento dos cogumelos. No entanto, a utilização do sulfito tem sido questionada pelos toxicologistas, em virtude das reações alérgicas apresentadas por pessoas sensíveis (Moraes, 1995). O metabissulfito de sódio comumente é empregado no branqueamento de cogumelos comestíveis e utilizado também como agente conservante, impedindo a atividade microbiana em conservas ou cogumelos frescos. Brennan et al. (1999) demonstraram que a dose comumente utilizada pelas indústrias (1g de metabissulfito de sódio/L) é ineficiente na manutenção da qualidade de cogumelos Agaricus bisporus fatiados. A dose mínima utilizada no trabalho para a inibição de bactérias Pseudomonas foi de $2 \mathrm{~g}$ de metabissulfito de sódio/L. Jorge \& Chaves (1992) utilizaram uma solução com 200 ppm de bissulfito de sódio para a imersão de Agaricus bisporus por 10 minutos, obtendo bons resultados no produto envasado.

A utilização de sachês de sorbitol fixados na parte interna das embalagens de cogumelos frescos Agaricus bisporus embalados com filmes plásticos de polivinilclorido (PVC) em bandejas de poliestiereno e acondicionados a $12^{\circ} \mathrm{C}$ promoveu uma diminuição da umidade na superfície dos cogumelos. A diminuição da umidade superficial não influiu na taxa de maturação dos cogumelos, mas reduziu o crescimento bacteriano e melhorou a coloração, provavelmente devido à redução da atividade bacteriana (Roy et al., 
1995a). Sorbitol e cloreto de sódio também foram testados como absorbantes da umidade superficial dos cogumelos Agaricus bisporus embalados com filme plástico de PVC em bandejas de poliestierno e mantidos sob refrigeração (Roy et al.; 1995b). A umidade relativa na parte interna do filme plástico não foi reduzida em comparação ao controle.

Sapers et al. (1994) apresentaram em seu trabalho várias soluções testadas para controlar o escurecimento em Agaricus bisporus minimamente processados, com o uso de: ácido ascórbico; ácido eritórbico; ácido ascórbico mono e trifosfatado; ácido cítrico; cisteína; N-acetil cisteína; EDTA ácido dissódico (etilenodiaminotetracetato ácido dissódico); ácido pirofosfato de sódio; hexametafosfato de sódio e cloreto de zinco. Utilizou-se também os antimicrobianos sulfato de estreptomicina; peróxido de hidrogênio; hipoclorito de sódio; benzoato de sódio e sorbato de potássio. Concluiu-se que as perdas de cogumelos devido à atividade bacteriana puderam ser controladas através do banho dos cogumelos em solução diluída de peróxido de hidrogênio. O escurecimento enzimático pode ser controlado utilizando-se solução contendo erisorbato de sódio; cisteína e EDTA ácido dissódico. O uso destes tratamentos nesta sequência constituiu um método eficiente no aumento da qualidade e extensão do tempo de conservação de Agaricus bisporus minimamente processados.

Soluções com glucana-delta-lactona ou ácido cítrico também foram utilizadas no processo de acidificação de Agaricus bisporus (Rodrigo et al.; 1999). A solução com glucana-delta-lactona manteve a coloração, textura e aparência do cogumelo como a solução de ácido cítrico, sem no entanto conferir gosto ácido ou aroma estranho ao produto.

Cogumelos Pleurotus sp. foram submetidos em processo de acidificação com soluções de ácidos cítrico, acético e lático antes do envasamento em salmoura contendo cloreto de cálcio, no trabalho de Nardim (1999). A acidificação com os ácidos acético e cítrico foram mais adequadas na avaliação sensorial do produto, principalmente nos quesitos cor e sabor. A 
salmoura com cloreto de cálcio apresentou-se translúcida aos 90 dias de armazenamento; o cálcio agiu como importante fator de retenção de sais, provocando diferenças significativas na textura do produto e no aspecto da solução salina acidificada. Os tratamentos de imersão em ácido cítrico foram benéficos com relação à cor do produto desidratado, que adquiriu uma tonalidade dourada.

O ácido cítrico atua bloqueando a atividade da enzima tirosinase, através de sua ação quelante sobre os íons cúpricos, que são constituintes da enzima. A atividade da tirosinase também pode ser reduzida através da redução do $\mathrm{pH}$; portanto o ácido cítrico exerce um duplo efeito inibitório sobre a enzima, além de ser sensorialmente aceito pela maioria dos consumidores. Não existem limites quanto à concentração do ácido cítrico na legislação brasileira, de forma que o bom senso e as avaliações sensorial, química e física determinam o sucesso de uma metodologia na conservação do produto fresco ou em conserva. De acordo com o Codex Alimentarius (FAO, 1995), podem ser utilizados como aditivos em cogumelos os ácidos acético, lático, cítrico e ascórbico, sem limites na concentração, com exceção do ácido acético para cogumelos em conserva, permitido na dosagem máxima de $20 \mathrm{~g} / \mathrm{kg}$ e para os ácidos lático e cítrico em cogumelos esterilizados, permitidos na dosagem máxima de $5 \mathrm{~g} / \mathrm{kg}$, separadamente ou em associação.

Coskuner \& Ozdemir (2000) realizaram o branqueamento de Agaricus bisporus com solução contendo $1 \mathrm{~g} / \mathrm{L}$ de ácido cítrico a $100^{\circ} \mathrm{C}$, imergindo os cogumelos durante 15 minutos; em seguida, foram armazenados a $5^{\circ} \mathrm{C}$ durante 7 dias. Após este período, realizaram avaliações da quantidade de micronutrientes presentes no controle e tratamento; os níveis de ferro, cobre, manganês e zinco não foram significativamente diferentes. Vivar-Quintana et al. (1999) realizaram o branqueamento de Agaricus bisporus através da imersão dos cogumelos em solução contendo ácido cítrico e ácido ascórbico. O branqueamento teve um efeito importante na conservação final do cogumelo, diminuindo a perda de peso e melhorando a coloração. A presença do ácido 
ascórbico aumentou a estabilidade da coloração e aceitabilidade do produto, inibindo o processo de escurecimento enzimático.

O peróxido de hidrogênio tem elevado poder bactericida, é de fácil aplicação e não apresenta toxidez residual após sua remoção com catalase. Seu mecanismo de ação não está totalmente elucidado; acredita-se que esteja envolvido com a oxidação de grupos sulfidrílicos das proteínas microbianas; daí seu poder bactericida. O peróxido de hidrogênio convertido em radicais hidroxilas altamente reativos por íons metálicos, pode degradar DNA, proteínas, polissacarídeos e lipídeos (Borges et al., 1989).

O Código de Regulamentos Federais dos EUA especifica que o peróxido de hidrogênio é permitido como agente antimicrobiano em doses entre 0,05\% e 0,15\%, desde que seu residual seja removido por método apropriado, químico ou físico, durante o processamento (Villalba, 1997).

Sapers et al. (1999) e Sapers et al. (2001) realizaram um experimento com a lavagem de Agaricus bisporus em solução de peróxido de hidrogênio a $5 \%$, juntamente com a aspersão de uma solução contendo erisorbato de sódio a 4\%, para evitar o escurecimento enzimático. O erisorbato de sódio é um agente antioxidante e pode previnir a perda de compostos fenólicos, ocasionados pela sua oxidação com peróxido de hidrogênio e pela polifenoloxidase. Através da microscopia eletrônica, observou-se que a lavagem provocou a quebra das hifas superficiais do cogumelo, provocando uma perda do conteúdo celular de seu interior. Apesar da utilização de solução contendo $5 \%$ de peróxido de hidrogênio, não foi registrado resíduo posterior nos cogumelos. Este resultado era esperado, devido ao alto teor de catalase endógena nos cogumelos, que foram liberadas durante a ruptura das hifas na lavagem.

Brennan et al. (2000) avaliaram o efeito das soluções de ácido cítrico e peróxido de hidrogênio na manutenção da qualidade e aumento do tempo de conservação em cogumelos frescos fatiados (Agaricus bisporus). A conservação máxima foi obtida através do tratamento que utilizou solução de 
ácido cítrico; o número de bactérias Pseudomonas foi reduzido significativamente pelos tratamentos com ácido cítrico e peróxido de hidrogênio em todas as parcelas. A resposta aos tratamentos sugeriu que o uso das soluções foi mais eficiente na redução da atividade bacteriana.

\subsection{Legislação}

De acordo com a Legislação Brasileira, referente ao Compêndio da Legislação de Alimentos (Brasil, 1987), os fungos designados cogumelos cultiváveis e comestíveis são descritos pela Resolução n.12, de 24 de julho de 1978, conforme transcrito abaixo:

\section{Definição}

Os cogumelos comestíveis são fungos pertencentes às classes dos ascomicetos e dos basidiomicetos. A espécie cultivada mais comum é o Agaricus bisporus (basidiomicetes).

\section{Designação}

O produto é designado simplesmente "cogumelo".

\section{Classificação}

a) Extra - Carpóforos inteiros, firmes, bem formados, véu fechado, tamanho uniforme, sem manchas ou marcas de parasitos. Quando lavados não devem apresentar odores estranhos (agentes branqueadores).

b) Comum - Carpóforos inteiros, firmes, sendo toleradas algumas manchas, tamanho e formato diversos.

\section{Características Gerais}

Os cogumelos comestíveis são constituídos por carpóforos não inteiramente desenvolvidos (botões) cortados pela base (não arrancados): são consistentes, isentos de manchas ou marcas de parasitos, e isentos da maior parte da matéria terrosa. Não podem conter detritos de substrato usado para o cultivo. Não podem apresentar-se fermentados e quando lavados, não devem apresentar odores estranhos. Tolera-se o tratamento de cogumelos com 
solução de bissulfito de sódio como agente branqueador. O resíduo máximo de $\mathrm{SO}_{2}$ é de 50 ppm.

\section{Características Organoléticas}

Os cogumelos devem obedecer ao seguinte padrão: bactérias do grupo coliforme de origem fecal - máximo de $2 \times 10^{2}$ UFC/g; ausência de Salmonellas em $25 \mathrm{~g}$.

Deverão ser efetuadas determinações de outros microrganismos e/ou substâncias tóxicas de origem microbiana, sempre que se tornar necessária a obtenção de dados adicionais sobre o estado higiênico-sanitário desta classe de alimento, ou quando ocorrerem toxi-infecções alimentares.

\section{Características Microscópicas}

Ausência de sujidades, parasitos e larvas.

\section{Rotulagem}

Quando embalado, o rótulo deve trazer a denominação "cogumelo", em seguida de sua classificação, podendo conter também a designação "champignon", no caso de se tratar do gênero Agaricus.

Convém ressaltar que para cogumelos processados a Legislação Brasileira ainda não definiu as normas necessárias para a padronização do produto. 


\section{MATERIAL E MÉTODOS}

A produção do inóculo e cogumelos foi desenvolvida em laboratório e estufa, no Departamento de Agroindústria, Alimentos e Nutrição, da Escola Superior de Agricultura "Luiz de Queiroz", campus da Universidade de São Paulo (USP) em Piracicaba - S.P.

O trabalho referente à vida útil dos cogumelos foi realizado no laboratório do Departamento de Entomologia e Irradiação de Alimentos do Centro de Energia Nuclear na Agricultura (CENA), Instituto Especializado da USP no campus "Luiz de Queiroz", em Piracicaba - S.P.

\subsection{Produção dos cogumelos}

\subsubsection{Produção do inóculo}

A produção do inóculo foi realizada através da obtenção de cogumelos frescos Pleurotus sajor-caju no laboratório comercial "Flora Speciosa", no município de São Pedro, S.P. Os cogumelos foram colhidos em estufas, provenientes de substrato à base de bagaço de cana-de-açúcar e farelo de trigo; foram transportados em sacos de polietileno à temperatura ambiente até o laboratório do Departamento de Agroindústria, Alimentos e Nutrição, onde foram lavados em água corrente para a retirada do substrato excedente, acondicionados em bandejas plásticas, embalados em filme plástico de PVC e armazenados sob refrigeração por 1 dia. Foram mergulhados em solução de hipoclorito de sódio $1 \mathrm{~N}$, da marca Quimex, a 0,1\% durante 5 
minutos para a desinfecção externa e foram colocados sobre papel absorvente para a retirada do excesso de umidade. A seguir, foram transferidos para uma câmara de fluxo laminar; o cogumelo foi rompido ao meio manualmente, expondo seu interior, de onde retirou-se com uma pinça esterilizada pedaços com cerca de $0,5 \mathrm{~cm}$ de diâmetro, transferindo-os para placas de Petri contendo meio de cultura Batata-Dextrose-Ágar (BDA), de acordo com Bononi et al. (1995); as placas foram seladas com filme plástico de PVC e incubadas a $25^{\circ} \mathrm{C}$, durante 10 dias. Estas foram utilizadas no preparo da "semente-inóculo"; repicagens do micélio de 2 placas para tubos de ensaio com meio BDA inclinado foram realizadas para a conservação do inóculo. Os tubos foram incubados em estufa com circulação de ar forçada a $25^{\circ} \mathrm{C}$ durante 7 dias. Após a miceliação completa do meio, foram envolvidos com filme plástico de PVC e armazenados a $4^{\circ} \mathrm{C}$, permanecendo desta forma viáveis por até quatro meses.

\subsubsection{Produção do "spawn" ou "semente-inóculo"}

O "spawn" ou "semente-inóculo" é o veículo de dispersão do micélio no substrato, sendo chamado pelos produtores simplesmente de semente. Para a produção da semente foram utilizados grãos de milho inteiros cozidos em água $\left(100^{\circ} \mathrm{C}\right)$ durante 15 minutos. Em seguida, os grãos foram drenados e resfriados; acrescentou-se $0,05 \%$ de carbonato de cálcio em relação ao peso seco dos grãos para a manutenção do pH do meio e adição de nutrientes. Os grãos foram transferidos para sacos de polipropileno (PP), de $25 \times 35 \mathrm{~cm}$, com espessura média de 0,6 mm e com um orifício de 1,5 cm de diâmetro para a passagem de ar na sua porção superior ( $2 \mathrm{~cm}$ abaixo da borda), vedado com filtro feito de Micropore ${ }^{\circledR}(2 \mathrm{~cm}$ de comprimento $\times 1 \mathrm{~cm}$ de largura). Os sacos foram autoclavados a 1 atmosfera durante 30 minutos; após o resfriamento efetuou-se a transferência do micélio das placas para estes com a utilização de pinças esterilizadas em câmara de fluxo laminar contínuo. A incubação foi realizada a $25^{\circ} \mathrm{C}$ por 10 dias em estufa com circulação de ar forçada. 


\subsubsection{Produção do substrato de cultivo}

\subsubsection{Produção do substrato de cultivo lavado}

A matéria-prima utilizada foi a cana-de-açúcar, variedade RB765418, cultivada no Setor de Açúcar e Álcool do Departamento de Agroindústria, Alimentos e Nutrição da ESALQ/USP. Os colmos sadios da cana-de-açúcar foram cortados, limpos e desfibrados em pedaços de 1 a $2 \mathrm{~cm}$ de comprimento por 0,5 a $1,0 \mathrm{~cm}$ de largura sendo em seguida passados por moenda para a extração do caldo.

Um lote deste bagaço fresco foi acondicionado em sacos de algodão crú e submetidos à pasteurização em água a $80-90^{\circ} \mathrm{C}$ durante 2 horas em tambor com capacidade para 1000 litros (Sturion \& Ranzani, 1997), sendo este o lote controle. Em seguida, o substrato foi drenado até atingir a umidade média de $60 \%$ (média de 3 repetições por amostra) através de prensa hidráulica e foi acondicionado em sacos de polietileno (PE) de $30 \times 40 \mathrm{~cm}$, com espessura média de $0,5 \mathrm{~mm}$, na quantidade de 700 gramas de matéria úmida por saco, juntamente com a semente preparada na proporção de $5 \%$ em relação ao peso úmido do substrato. A semente foi retirada dos sacos e separada manualmente, pesando-se a quantidade necessária para cada substrato.

O outro lote foi lavado em água corrente à temperatura ambiente durante uma hora em um aparelho adaptado da lavagem de toletes de mandioca. Este aparelho consiste em uma peneira cilindrica que realiza movimentos rotatórios por meio de uma correia lisa; a entrada de água possibilita a lavagem do material no interior do cilindro. A água, juntamente com outros elementos, sai do aparelho com a rotação do cilindro, através de força centrífuga (Figura 2). Após a lavagem, o bagaço foi drenado até atingir umidade média de $60 \%$ (média de 3 repetições por amostra) através de prensa hidráulica e foi acondicionado em sacos de polietileno (PE) de $30 \times 40 \mathrm{~cm}$, com espessura média de 0,5 mm, na quantidade de 700 gramas de matéria úmida por saco, 
juntamente com a semente preparada, na proporção de 5\% em relação ao peso úmido do substrato. Os sacos com os substratos preparados foram conduzidos para uma estufa em alvenaria e telhas de barro e alojados em prateleiras de madeira, onde permaneceram durante os períodos de incubação e colheita. A temperatura do ambiente variou entre $20-25^{\circ} \mathrm{C}$ e a umidade relativa do ar manteve-se entre 70-90\%. As condições de temperatura e umidade do ambiente foram reguladas por termohigrômetro microprocessado MF $530 \mathrm{C}$; a luminosidade do ambiente foi natural e a quantidade de gás carbônico foi controlada através de um exaustor de $25 \mathrm{~cm}$ de diâmetro e motor $1 / 25 \mathrm{CV}$, que foi ligado 2 vezes ao dia durante 1 hora na fase de produção dos cogumelos.

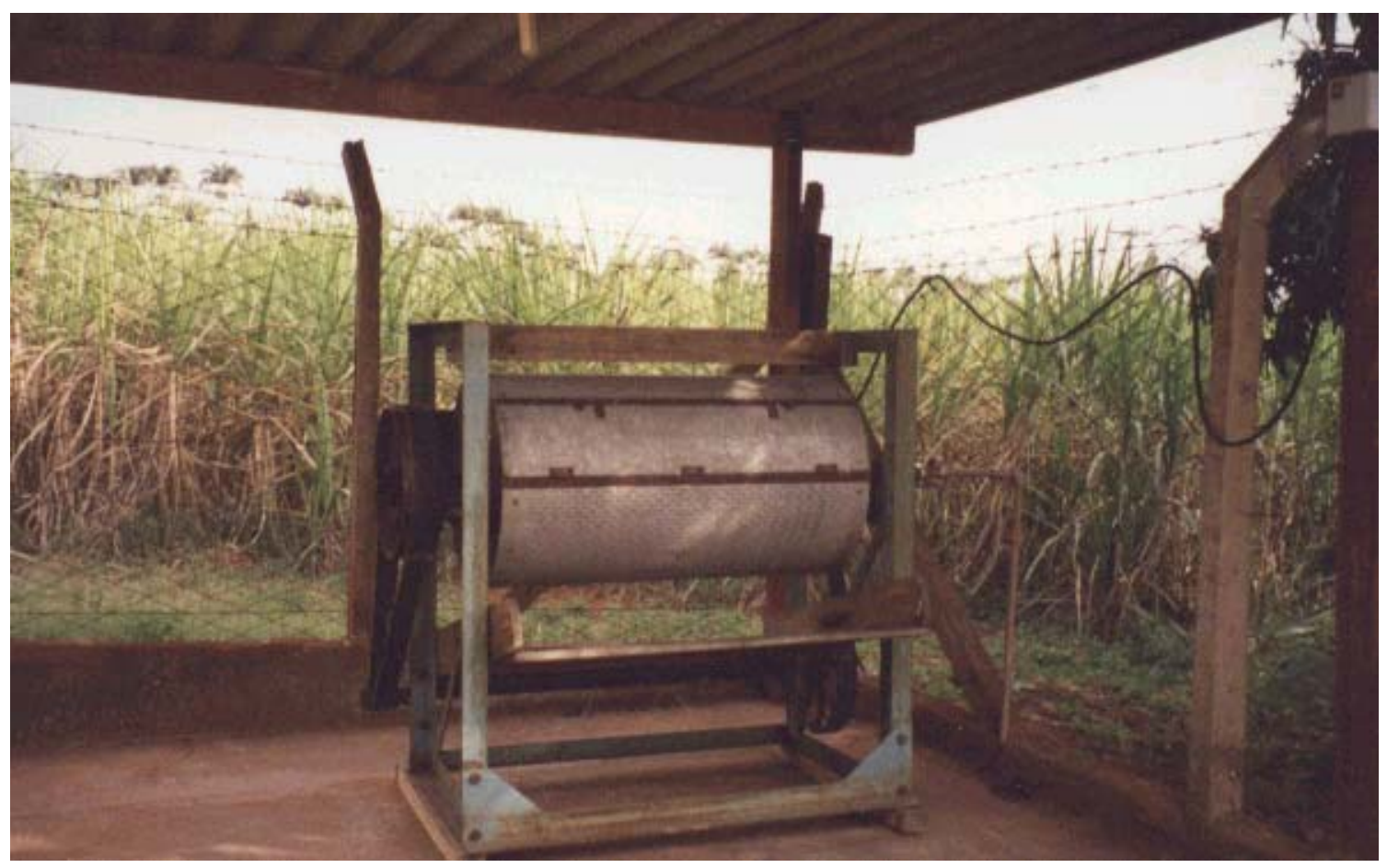

Figura 2 - Aparelho utilizado na lavagem do bagaço de cana-de-açúcar. 
Cana-de-açúcar (Variedade RB76-5418)

$\sqrt{3}$

Colmos cortados, limpos, desfibrados

৫)

Pasteurização $\left(80-90^{\circ} \mathrm{C}\right.$, por 2 horas) (controle)

$\sqrt{3}$

Prensagem $\unlhd$

Lavagem (água corrente, por 1 hora)

\author{
$\sqrt{3}$ \\ Inoculação (5\% sementes) \\ $\sqrt{3}$ \\ Acondicionamento \\ (5\% sementes)
}

(1)

$\unlhd$

Incubação (20-25ㄷ, 80\% U.R., durante 15-20 dias)

$\sqrt{3}$

Colheita $\left(20-25^{\circ} \mathrm{C}, 90 \%\right.$ U.R., durante $25-30$ dias)

Figura 3 - Fluxograma de produção do substrato de cultivo lavado. 


\subsubsection{Produção do substrato de cultivo suplementado}

O preparo do substrato suplementado foi realizado após o término da colheita do primeiro experimento. As prateleiras utilizadas foram lavadas com água e detergente neutro, assim como as paredes internas e o assoalho da estufa. Em seguida, o ambiente foi pulverizado com calda bordaleza (10 litros de água misturados a $100 \mathrm{~g}$ de cal virgem e $100 \mathrm{~g}$ de sulfato de cobre) para a desinfecção do local. O período de descanso da estufa após a pulverização foi de 2 dias.

Nos substratos suplementados foi utilizada a cana-de-açúcar, variedade RB76 - 5418, cultivada no Setor de Açúcar e Álcool do Departamento de Agroindústria, Alimentos e Nutrição da ESALQ/USP. Os colmos sadios da cana-de-açúcar foram cortados, limpos e desfibrados em pedaços de 1 a $2 \mathrm{~cm}$ de comprimento por 0,5 a 1,0 cm de largura sendo em seguida passados por moenda para a extração do caldo. O bagaço foi lavado em água corrente à temperatura ambiente por uma hora em aparelho adaptado, de acordo com a metodologia já descrita anteriormente. Após a lavagem, o bagaço foi drenado até atingir umidade média de $60 \%$ (média de 3 repetições por amostra) através de prensa hidráulica e foi dividido em 3 lotes; o controle foi acondicionado em sacos de polietileno (PE) de $30 \times 40 \mathrm{~cm}$, com espessura média de 0,5 mm, na quantidade de 700 gramas de matéria úmida por saco, juntamente com a semente preparada, na proporção de 5\% em relação ao peso úmido do substrato.

O segundo lote recebeu suplementação orgânica, realizada através da adição de quirera de milho comum cozida durante 15 minutos ao substrato, na proporção de $10 \%$ sobre o peso úmido do mesmo (650 gramas), juntamente com a semente ( $5 \%$ em relação ao peso úmido do substrato) no momento do acondicionamento nos sacos de polietileno.

O terceiro lote foi preparado conforme descrito no controle; após 10 dias de incubação na estufa, recebeu suplementação mineral, realizada através 
da injeção de $20 \mathrm{~mL}$ de solução nutritiva na parte superior dos sacos, quando estes já se apresentavam parcialmente miceliados. Esta solução nutritiva foi adaptada do cultivo hidropônico da alface crespa, de acordo com o Boletim Técnico 100 do Instituto Agronômico de Campinas, IAC (1996), com aumento na concentração dos nutrientes da solução hidropônica em 50 vezes, com exceção do ferro EDTA, que foi aumentado em 5 vezes, como indicado na Tabela 1.

Os lotes preparados foram conduzidos para estufa em alvenaria e telhas de barro e alojados em prateleiras de madeira, onde permaneceram durante o período de incubação e colheita. A temperatura do ambiente variou entre $20-25^{\circ} \mathrm{C}$ e a umidade relativa do ar manteve-se entre $70-90 \%$. As condições de temperatura e umidade do ambiente foram reguladas por termohigrômetro microprocessado MF 530 C; a luminosidade do ambiente foi natural e a quantidade de gás carbônico foi controlada através de um exaustor de $25 \mathrm{~cm}$ de diâmetro e motor $1 / 25 \mathrm{CV}$, que foi ligado 2 vezes ao dia durante 1 hora na fase de produção dos cogumelos.

Tabela 1. Composição da solução nutritiva em $200 \mathrm{~mL}$ de água destilada.

\begin{tabular}{ll}
\hline Adubos & Quantidade \\
\hline Nitrato de Cálcio & $7,5 \mathrm{~g}$ \\
Nitrato de Potássio & $5,0 \mathrm{~g}$ \\
Fosfato Monoamônio (MAP) & $1,5 \mathrm{~g}$ \\
Sulfato de Magnésio & $4,0 \mathrm{~g}$ \\
Ferro EDTA & $0,25 \mathrm{~mL}$ \\
Solução de Micronutrientes $^{1}$ & $1,0 \mathrm{~mL}$ \\
\hline
\end{tabular}

${ }^{1}$ Sulfato de Manganês (5,0 g); Sulfato de Zinco (0,5 g); Ácido Bórico (1,0 g); Sulfato de Cobre $(0,2 \mathrm{~g})$ e Molibdato de Sódio $(0,2 \mathrm{~g})$ em 1 litro de água destilada. 
Cana-de-açúcar (Variedade RB76-5418)

$\sqrt{3}$

Colmos cortados, limpos, desfibrados

$\sqrt{3}$

Lavagem (água corrente, por 1 hora)

$\sqrt{3}$

Prensagem

凹

\)

Inoculação

Inoculação +

(1 lote-controle)

quirera milho $\left(2^{\circ}\right.$ lote $)$

noculação

$\sqrt{ }$

( $3^{\circ}$ lote)

$\S$

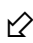

Acondicionamento

$\sqrt{3}$

Incubação $\left(20-25^{\circ} \mathrm{C}, 80 \%\right.$ U.R., durante $15-20$ dias $)$

勺

$\searrow$

Solução injetada no $3^{\circ}$ lote após 10 dias de incubação

$\sqrt{3}$

$\sqrt{3}$

Colheita $\left(20-25^{\circ} \mathrm{C}, 90 \%\right.$ U.R., durante $25-30$ dias)

Figura 4 - Fluxograma de produção do substrato de cultivo suplementado. 


\subsection{Conservação dos cogumelos}

\subsubsection{Coleta dos cogumelos}

Os cogumelos Pleurotus sajor-caju foram colhidos durante o primeiro fluxo produtivo do experimento, provenientes do substrato de bagaço de canade-açúcar lavado e suplementado com solução mineral, por este apresentar-se mais homogêneo e com poucas contaminações. Os cogumelos foram colhidos no mesmo dia, totalizando $1500 \mathrm{~g}$, e foram colocados em bandejas higienizadas com solução de hipoclorito de sódio a $0,1 \%$, sendo levados em seguida ao laboratório do CENA para a realização dos tratamentos. Os cogumelos foram individualizados para uma melhor manipulação, pois têm o hábito de nascerem agrupados, formando um "cacho"; foram escolhidos os cogumelos inteiros e de maior tamanho, sem contaminações ou injúrias aparentes. Foi retirado o substrato residual do estipe dos cogumelos manualmente e foram divididos em 4 porções com $200 \mathrm{~g}$ cada, para a imersão nas diferentes soluções e controle.

\subsubsection{Preparo das soluções}

As soluções preparadas de acordo com Brennan et al. (2000) foram utilizadas para os diferentes tratamentos; a solução com ácido cítrico foi preparada diluindo-se $40 \mathrm{~g}$ de ácido cítrico 1N, da marca Quimex, em $1000 \mathrm{~mL}$ de água destilada; a solução de peróxido de hidrogênio foi preparada diluindose $50 \mathrm{~mL}$ de uma solução pré-diluída $(167 \mathrm{~mL}$ de peróxido de hidrogênio 30 volumes, da marca Ecibra, em $833 \mathrm{~mL}$ de água destilada) em $1000 \mathrm{~mL}$ de água destilada. A água destilada (1000 mL) pura também foi utilizada como um tratamento; o controle não foi imerso em nenhum tipo de solução. As soluções foram acondicionadas em recipientes com capacidade para $2000 \mathrm{~mL}$, com os rótulos designando os diferentes tratamentos.

Os cogumelos foram imersos por 10 minutos nas respectivas 
soluções, sendo em seguida colocados sobre papel absorvente por 2 minutos para a retirada da umidade excedente; foram acondicionados em bandejas de poliestireno com $50 \mathrm{~g}$ cada e embalados com filme plástico de PVC de 0,2 mm de espessura. A seguir, foram armazenados a $4^{\circ} \mathrm{C}$ por 10 dias para a realização das análises.

\subsection{Avaliações}

\subsubsection{Produção dos cogumelos}

Contaminação: através da quantificação do número de repetições que apresentaram contaminações até o final do experimento, calculado em termos de porcentagem.

Eficiência biológica (EB): representa a produtividade do substrato em cada tratamento através da fórmula:

$E B \%=$ peso fresco total dos cogumelos $/$ peso seco do substrato inicial $x$ 100

de acordo com Chang et al. (1981) e Maziero et al. (1992).

Eficiência biológica média (EBM): obtida através da média dos valores da EB das repetições em cada tratamento.

Análise química do bagaço de cana lavado e do Pleurotus sajorcaju: obtida através da média de 3 sub-amostras analisadas de forma independente através de espectrofotometria, realizadas no laboratório de Química do Centro de Energia Nuclear na Agricultura (CENA), Campus "Luiz de Queiroz", da Universidade de São Paulo. 


\subsubsection{Análises físicas dos cogumelos}

Os tratamentos foram avaliados logo após sua imersão nas diferentes soluções (dia 0) e após transcorridos 5 e 10 dias, sendo denominados dia 5 e dia 10, respectivamente. As análises realizadas foram:

Peso: medido em gramas através da pesagem individual das bandejas em balança eletrônica, marca OHAUS, modelo Precision Plus, com 3 casas decimais após a vírgula, excetuando-se a tara.

Firmeza: medido por resistência ao penetrômetro de sensibilidade 1,5 N (Newton) FDN 2, marca Wagner Dial Force, com média de 3 cogumelos por repetição.

Cor: utilização de colorímetro Minolta CR-200 b de $8 \mathrm{~mm}$ de diâmetro, para a medição de 3 cogumelos por repetição, registrando mudanças na coloração, brilho e saturação das cores através do valores $L^{*}, a^{*}$ e $b^{*}$, previamente calibrado em superfície branca de acordo com padrões préestabelecidos segundo Bible \& Singha, $1993^{1}$ e Mutschler et al., $1992^{2}$, citados por Villalba (1997) e de acordo com a Comissão Internacional de Iluminação (CIE $1976 L^{*}, a^{*}, b^{*}-$ CIELAB).

${ }^{1}$ BIBLE, B.B.; SINGHA, S. Canopy position influences CIELAB coordinates of peach color. HortScience, v.28, n.10, p.992-993, 1993.

2 MUTSCHLER, M.A.; WOLFE, D.W.; COBB, E.D.; YOURSTONE, K.S. Toamyo fruit quality and shelf life in hybrids heterozigous for the alc ripening mutant. HortScience, v.27, n.4, p.352355, 1992. 
Segundo McGuire (1992), o valor L* ou coeficiente de luminosidade é uma escala monocromática que expressa a quantidade de luz refletida, onde $L^{*}$ $=100$ representa o branco puro e $L^{*}=0$ representa o preto, sendo inserido perpendicularmente ao centro do disco de cores (Figura 5). Esta escala é análoga à escala de cores de Munsell, com valores de 0 a 10 para determinação do grau de luminosidade. Para um determinado valor de $\mathrm{Li}^{*}$, as coordenadas retangulares $\left(\mathrm{a}^{*}, \mathrm{~b}^{*}\right)$ determinam a coloração de um objeto. Conforme o disco de cores, temos um centro de origem acromático ou cinza, com valores de $a^{*}=0$ e $b^{*}=0$. No eixo horizontal, valores positivos de $a^{*}$ indicam o tom vermelho púrpura, enquanto que valores negativos indicam o verde azulado. No eixo vertical, valores positivos de $b^{*}$ indicam o tom amarelo e valores negativos indicam o tom azul. A resultante encontrada através dos valores de $L^{*}, a^{*} e b^{*}$ determina a coloração do objeto analisado.

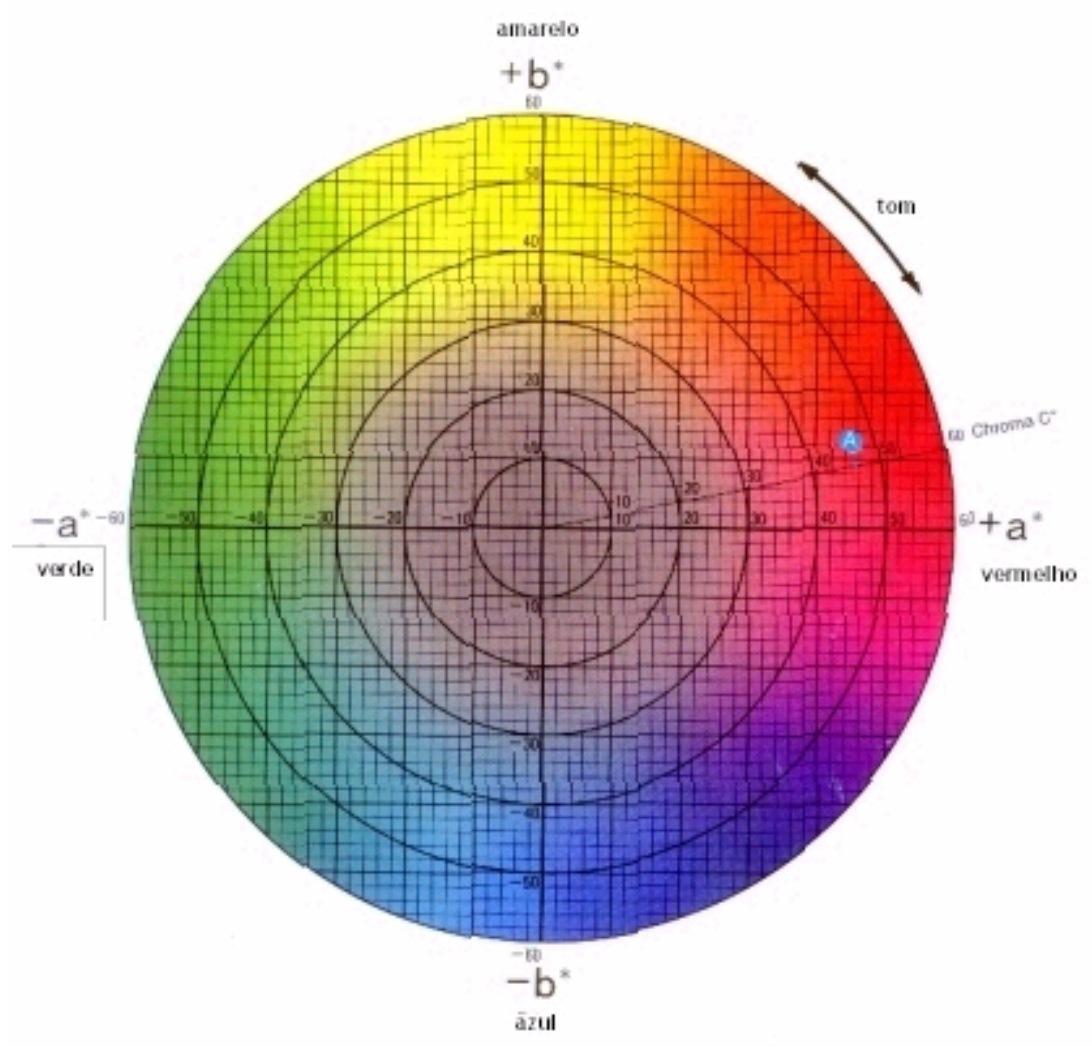

Figura 5 - Disco de Cores. 


\subsection{Estatística}

\subsubsection{Produção dos cogumelos}

\subsubsection{Produção do substrato de cultivo lavado}

O trabalho foi instalado sob delineamento experimental com distribuição inteiramente ao acaso, com 2 tratamentos e 10 repetições. O teste de média utilizado foi o teste $\mathrm{T}$, de comparação entre duas médias, ao nível de 5\% de significância. O programa utilizado para a realização da análise estatística foi o Statistical Analyses System (SAS).

\subsubsection{Produção do substrato de cultivo suplementado}

O trabalho foi instalado sob delineamento experimental com distribuição inteiramente ao acaso, com 3 tratamento e 10 repetições. O teste de média utilizado foi o teste de Tukey, ao nível de 5\% de significância. Para a análise estatística foi utilizado o programa SAS.

\subsubsection{Conservação dos cogumelos}

O trabalho foi instalado sob delineamento experimental com distribuição inteiramente ao acaso, com 4 tratamentos e 5 repetições. O teste de média utilizado foi o teste de Tukey, ao nível de 5\% de significância. Para a análise estatística foi utilizado o programa SAS. 


\section{RESULTADOS E DISCUSSÃO}

\subsection{Produção dos cogumelos}

\subsubsection{Produção do substrato de cultivo lavado}

\subsubsection{Eficiência biológica (EB) e eficiência biológica média (EBM)}

Os valores de EB foram encontrados através da fórmula descrita no capítulo 3; esta fórmula é amplamente utilizada na produção de cogumelos comestíveis, sendo adotada como parâmetro de comparação na maioria dos trabalhos científicos. Através da média dos valores da EB das repetições, conforme a Tabela 2, obteve-se a EBM dos tratamentos. Os resultados foram analisados através do Teste T, onde a EBM foi comparada, de acordo com a Tabela 3.

A corrida do micélio pelo substrato pode ser observada a partir do terceiro dia após a inoculação da semente. Foram observados ao redor das sementes espalhadas pelo substrato halos de coloração rosa claro no bagaço da cana, indicando o início da degradação do substrato pelo fungo. O micélio do cogumelo, caracterizado pelo conjunto de suas hifas, apresentou um aspecto cotonoso, semelhante ao algodão, com coloração branco-amarelada.

A indução dos primórdios ocorreu entre 15-17 dias da produção do substrato; o primeiro fluxo produtivo ou colheita ocorreu 20 dias após seu preparo, apresentando maior produtividade em relação ao segundo e terceiro fluxos. Os cogumelos Pleurotus sajor-caju nasceram agrupados em cachos, 
apresentando coloração marrom-acinzentada, característica da espécie. O segundo e terceiro fluxos ocorreram 15 e 30 dias após a primeira produção, respectivamente, sendo inferior à primeira colheita, com cogumelos menores $\mathrm{e}$ mais finos. A coloração dos cogumelos manteve-se igual à primeira colheita; o intervalo de descanso entre os fluxos produtivos foi de 7-8 dias. Este comportamento foi semelhante em todas as repetições, com exceção daquelas perdidas devido à contaminação.

Deste modo, obteve-se uma colheita a cada 15 dias, totalizando um período de 50 dias entre o início da miceliação nos substratos e a última colheita viável. Os períodos registrados em cada etapa foram semelhantes ao observado nos cultivos comerciais, com diferença somente na quantidade de cogumelos produzidos. A partir da terceira colheita ou fluxo produtivo, tornou-se inviável a manutenção dos substratos nas estufas devido à baixa produtividade dos mesmos. Os substratos exauridos foram esfarelados e aproveitados como adubo orgânico, devido ao seu conteúdo em nitrogênio e outros minerais provenientes do micélio do cogumelo. 
Tabela 2. Produção, contaminação e EB dos substratos lavado e pasteurizado.

\begin{tabular}{ccccccc}
\hline Trat. & 1 $^{\circ}$ fluxo $(\mathrm{g})$ & $2^{\circ}$ fluxo $(\mathrm{g})$ & $3^{\circ}$ fluxo $(\mathrm{g})$ & Contamin. & Peso(g) & EB\% \\
\hline P & 16,01 & 28,04 & $*$ & presente & 44,05 & 11,01 \\
P & 44,21 & 19,71 & 38,51 & ausente & 102,43 & 25,61 \\
P & 29,97 & 46,32 & 28,27 & ausente & 104,56 & 26,14 \\
P & 23,37 & $*$ & $*$ & presente & 23,37 & 5,84 \\
P & 61,38 & 10,84 & 31,85 & ausente & 104,07 & 26,02 \\
P & 36,78 & $*$ & $*$ & presente & 36,78 & 9,20 \\
P & 25,9 & 7,14 & $*$ & presente & 33,04 & 8,26 \\
P & 42,32 & $*$ & $*$ & presente & 42,32 & 10,58 \\
P & 21,1 & 15,32 & $*$ & presente & 36,42 & 9,11 \\
P & 27,21 & $*$ & $*$ & presente & 27,21 & 6,80 \\
L & 43,19 & 11,83 & $*$ & presente & 55,02 & 13,76 \\
L & 18,72 & 21,53 & 18,8 & ausente & 59,05 & 14,76 \\
L & 53,99 & 6,38 & 10,33 & ausente & 70,70 & 17,68 \\
L & 42,17 & 16,09 & 7,05 & ausente & 65,31 & 16,33 \\
L & 38,52 & 6,27 & $*$ & presente & 44,79 & 11,20 \\
L & 53,77 & 13,4 & 20 & ausente & 87,17 & 21,79 \\
L & 125,4 & 27,88 & $*$ & presente & 153,28 & 38,32 \\
L & 32,85 & 19,42 & 15,2 & ausente & 67,47 & 16,87 \\
L & 59,03 & 28,02 & $*$ & presente & 87,05 & 21,76 \\
\hline
\end{tabular}

* Interrupção da produção devido à contaminação do substrato.

$\mathrm{L}$ refere-se ao substrato lavado e $\mathrm{P}$ ao substrato pasteurizado (controle). 
Os resultados obtidos dos substratos pasteurizado e lavado através da análise estatística das EBM demonstraram que não existiu diferença em termos produtivos entre os tratamentos, de acordo com a Tabela 3.

Tabela 3. EBM entre os tratamentos lavado e pasteurizado.

\begin{tabular}{ccc}
\hline Tratamento & EBM(\%) & Desvio Padrão \\
\hline Lavado & 19,16 & 7,97 \\
Pasteurizado & 13,85 & 8,46 \\
\hline
\end{tabular}

Nota: O valor T tabelado é referente ao nível de $5 \%$ de probabilidade.

Teste T: para H0, ou hipótese de nulidade, as variâncias são iguais; o valor de T tabelado para os substratos lavado e pasteurizado é de 2,26 de acordo com os graus de liberdade dos tratamentos. O valor de $\mathrm{T}$ calculado é igual a 1,4; como este valor não atingiu o limite de $5 \%$ de probabilidade em ambos os casos (foi menor que 2,26 ), aceitou-se a hipótese de nulidade, onde a EBM do substrato lavado e do pasteurizado foram iguais. Ou seja, os tratamentos não diferiram entre si, de acordo com a análise estatística.

A variação da EB dentro de cada tratamento foi alta, apontada pelo desvio padrão; no bagaço pasteurizado a EB variou de 5,84\% a $26,14 \%$, com a EBM igual a $13,85 \%$. Já no bagaço lavado, a EB variou de $11,20 \%$ a $38,3 \%$, sendo a EBM de 19,16\%. A EB obtida foi inferior à EB registrada por outros autores. A grande variação da EB deveu-se à perda de repetições nos tratamentos, devido as contaminações ocorridas nos substratos, como mostra a Tabela 2. Colauto \& Eira (1995) obtiveram EB de 39,9\% na produção de Pleurotus sajor-caju em substrato à base de bagaço de cana-de-açúcar e palha de feijoeiro, enquanto que Sturion \& Oeterrer (1995) obtiveram EB de 48,29\% na produção de Pleurotus sajor-caju em bagaço de cana e palha da folha da 
bananeira. O uso exclusivo do bagaço de cana para a produção do substrato também contribuiu para a redução da EB no experimento, pois o bagaço é pobre em nutrientes, sendo fonte principalmente de celulose, hemicelulose e lignina. Em relação ao conteúdo de minerais no bagaço de cana, foi realizada uma análise química, determinando seus valores médios, conforme a Tabela 4. Quanto ao conteúdo de nitrogênio em Pleurotus sajor-caju, observou-se através da análise química uma indicação da possível capacidade de fixação de nitrogênio pelo cogumelo ou por microrganismos presentes no sistema. A Tabela 4 mostra o conteúdo em nitrogênio do bagaço de cana lavado e do cogumelo:

Tabela 4. Análise química do bagaço de cana-de-açúcar lavado sem suplementação e do cogumelo Pleurotus sajor-caju coletado deste substrato.

\begin{tabular}{lllllllllllll}
\hline Amostra & $\mathrm{N}$ & $\mathrm{K}$ & $\mathrm{P}$ & $\mathrm{Mg}$ & $\mathrm{S}$ & $\mathrm{Ca}$ & $\mathrm{Al}$ & $\mathrm{Na}$ & $\mathrm{Fe}$ & $\mathrm{Zn}$ & $\mathrm{Cu}$ & $\mathrm{Mn}$ \\
\hline Bagaço & $0,48^{\star}$ & $0,12^{\star}$ & 225 & 425 & 294 & 654 & 39 & 50 & 96 & 23 & 2,4 & 20 \\
Cogumelo & $17,4^{\star}$ & $4,32^{\star}$ & $1,97^{*}$ & $0,46^{\star}$ & $0,77^{*}$ & 102 & 42 & 215 & 163 & 192 & 14 & 21 \\
\hline
\end{tabular}

* Expressos em \% na matéria seca (M.S.); os demais elementos são expressos em $\mu \mathrm{g} / \mathrm{g}$ na M.S.

O balanço do nitrogênio nas amostras analisadas mostrou uma diferença de aproximadamente $17 \%$ entre o bagaço e o cogumelo; esta diferença pode ser reduzida considerando a porcentagem de nitrogênio contida no milho utilizado como veículo de dispersão do micélio (semente), que é de1,83\% na M.S. Apesar da presença do milho no substrato de cultivo, o acréscimo de nitrogênio no cogumelo foi significativo. Este resultado pôde ser melhor avaliado em função da utilização do bagaço de cana sem suplementação; desta forma, o acréscimo de nitrogênio no cogumelo tornou-se evidente, reforçando as hipóteses de fixação de nitrogênio pelo Pleurotus sp. 
(Ortega et al., 1992; Sturion \& Oetterer, 1995 e Patrabansh \& Madan, 1997) ou através de microrganismos associados, como bactérias (Yara, 2002). Este último trabalho registrou a ocorrência de microrganismos associados à cogumelos do gênero Pleurotus, semelhantes à bactéria Burkholderia sp., encontrados em vacúolos junto às hifas do micélio e que podem estar relacionados com a fixação de nitrogênio neste sistema. Outro ponto a ser avaliado em relação à fixação de nitrogênio é a presença de quitina, constituinte da parede celular dos fungos, um polissacarídeo que apresenta nitrogênio em sua estrutura (Manzi et al., 1999). Este elemento pode superestimar as quantidades de nitrogênio presente nos cogumelos durante as análises químicas e deve ser avaliado conjuntamente.

Os valores de potássio $(K)$, fósforo $(P)$, magnésio $(M g)$, enxofre $(S)$, sódio $(\mathrm{Na})$, ferro $(\mathrm{Fe})$, zinco $(\mathrm{Zn})$ e cobre $(\mathrm{Cu})$ no cogumelo analisado foram maiores em relação ao bagaço de cana; o conteúdo de cálcio do cogumelo decresceu e os valores de alumínio (Al), manganês (Mn) e boro (B) mantiveram-se semelhantes nas duas amostras. Em relação à quantidade de macrominerais presentes, têm-se em ordem decrescente os elementos: K, P, S, $\mathrm{Mg}$ e Ca; quanto à quantidade de microminerais, têm-se em ordem decrescente os elementos: Zn, Fe, Cu, Mn e B. De acordo com Chang \& Miles, (1984), o mineral mais abundante nos cogumelos é o potássio, seguido de fósforo, sódio, cálcio e magnésio, constituindo cerca de $56 \%$ a $70 \%$ do total de cinza da matéria orgânica.

Segundo Sturion \& Ranzani (1997), os cogumelos Pleurotus são boa fonte de minerais. Entre os macrominerais presentes em maiores quantidades estão o potássio, o fósforo e o magnésio. Entre os microminerais presentes estão o cobre, o zinco, o ferro, o manganês, o molibdênio e o cádmio. O Pleurotus, assim como outros tipos de cogumelos, tem a capacidade de bioconcentrar metais pesados, como o cobre, o zinco, o cádmio e o mercúrio. Por esta razão, o monitoramento periódico da presença destes metais nos 
corpos de frutificação é recomendado, principalmente quando as condições de cultivo variarem. Segundo Furlan (1994), a composição química dos corpos de frutificação pode variar de acordo com a espécie e linhagem avaliada, bem como as condições de cultivo, clima e solo.

Variações no conteúdo mineral podem ocorrer entre os cogumelos, exceto no conteúdo de potássio. Quando a palha é utilizada como substrato, o conteudo mineral nos cogumelos apresenta redução nos teores de sódio e fósforo; o conteúdo em fósforo é relativamente alto em cogumelos desenvolvidos sobre resíduos da cultura do algodão (Chang et al., 1981).

\subsubsection{Contaminações}

A contaminação por fungos e bactérias competidoras ocorreu em quase todas as repetições do tratamento pasteurizado (70\%), geralmente após o primeiro fluxo produtivo. No tratamento com substrato lavado, a porcentagem de contaminação ficou em 44,44\%, aparecendo após o segundo fluxo produtivo. Estas contaminações ocorreram devido a um enfraquecimento do micélio do cogumelo e são observadas na maior parte dos cultivos comerciais, geralmente após a colheita. A maior porcentagem de contaminação no substrato pasteurizado pode ter ocorrido devido ao sistema de pasteurização adotado, com a imersão do substrato em água a $80-90^{\circ} \mathrm{C}$. Durante o processo de lavagem, uma parte dos contaminantes superficiais do substrato foram lixiviados, juntamente com sólidos solúveis do bagaço da cana-de-açúcar. O teor em sólidos solúveis da cana-de-açúcar desfibrada variou de 16,5 a 18,7 Brix, enquanto que o teor em sólidos solúveis do bagaço lavado ficou entre 0,3 a $0,5^{\circ}$ Brix, e do bagaço pasteurizado ficou entre 1,2 a $1,8^{\circ}$ Brix. A baixa quantidade de sólidos solúveis, principalmente açúcares no substrato lavado é importante para a redução da contaminação, uma vez que o processo de pasteurização foi excluído desta metodologia. No método tradicional de cultivo 
de cogumelos comestíveis, a compostagem tem a função de digerir os açúcares de fácil degradação através da atuação de microrganismos presentes nos resíduos que compõe o substrato, além de disponibilizar alguns nutrientes presentes na biomassa e torná-la mais homogênea (Bononi et al., 1995). Os microrganismos competidores são em seguida parcialmente eliminados pelo processo de pasteurização, ou totalmente pelo processo de esterilização do composto, sendo em seguida realizada a inoculação da semente. Com a utilização da lavagem do bagaço em água à temperatura ambiente obteve-se um substrato apropriado para o cultivo de Pleurotus sajor-caju, sem que fossem necessários os processos de compostagem e pasteurização comumente utilizados. O substrato lavado apresentou estabilidade em relação ao baixo desenvolvimento de microrganismos competidores, sendo um meio de cultivo estável para a produção de Pleurotus sajor-caju; o micélio do cogumelo desenvolveu-se normalmente, e a produção foi satisfatória. Esta metodologia de produção de substrato pode efetivamente auxiliar a produção de cogumelos em pequenas propriedades, pois reduz gastos com mão-de-obra e equipamentos, além de economizar tempo do produtor. O bagaço de cana-de-açúcar passa pelo processo de lavagem simples e é inoculado imediamente com a semente, seguindo para a estufa de produção. A compostagem torna-se desnecessária, assim como a pasteurização. $O$ uso de tratores para o transporte e reviragem das pilhas de compostagem torna-se dispensável, assim como a montagem e manutenção de uma caldeira para a produção de vapor que é utilizado na câmara de pasteurização. A água utilizada na lavagem do bagaço poderá ser reaproveitada em hortas e pomares e o substrato residual poderá ser utilizado como adubo orgânico ou na alimentação animal, principalmente de ruminantes.

Desta forma, observou-se que o processo de lavagem simples do bagaço de cana-de-açúcar foi eficiente no processo produtivo de Pleurotus sajor-caju, uma vez que sua produção (EB) foi semelhante à do substrato pasteurizado (controle) e a porcentagem de contaminação foi inferior em relação ao mesmo. Assim, a lavagem simples do substrato de bagaço de cana- 
de-açúcar fresco pode substituir a fase de pasteurização do cultivo convencional de Pleurotus sajor-caju, etapa que necessita de mão-de-obra treinada e implementos específicos, que encarece o custo de produção e limita o acesso do pequeno produtor rural ao seu cultivo.

\subsubsection{Produção do substrato de cultivo suplementado}

\subsubsection{Eficiência biológica (EB) e eficiência biológica média (EBM)}

Apesar da lavagem simples do bagaço ser eficiente no controle de microrganismos competidores, a EB alcançada foi inferior à obtida em trabalhos que utilizaram os processos normais de produção e suplementação com diversos compostos, com maior porcentagem de nitrogênio e outros minerais. Desta forma, a suplementação do bagaço lavado com quirera de milho ou solução mineral foi realizada para a obtenção de melhores resultados.

A indução dos primórdios ocorreu entre 14-17 dias da inoculação do substrato e o primeiro fluxo produtivo ocorreu após 3 dias da formação dos primórdios, com tempo de colheita de 7 dias, apresentando maior produtividade em relação ao segundo e terceiro fluxos. Estes ocorreram 15 e 30 dias após a primeira produção, respectivamente; o intervalo de descanso entre os fluxos foi de 7 dias, obtendo-se uma colheita a cada 15 dias, totalizando um período de 50 dias entre o início da miceliação nos substratos e a última colheita.

A EB do substrato lavado (controle) variou de 16,64\% a 31,83\%, sendo sua EBM de 26,63\%. A EB do substrato lavado com suplementação orgânica variou de 12,03\% a 21,43\%, sendo sua EBM de 15,66\%; a EB do substrato lavado com suplementação mineral variou de $34,24 \%$ a $27,14 \%$, sendo sua EBM de 30,03\% (Tabela 5). A variação entre as repetições diminuíu em relação ao primeiro experimento, provavelmente devido à melhor adequação do método de lavagem simples no preparo do substrato e a menor porcentagem de contaminação nos tratamentos. As EBM obtidas em cada 
tratamento foram analisadas e chegou-se aos resultados onde: os substratos lavado e lavado com suplementação mineral não diferiram entre si, embora a EBM do tratamento com suplementação mineral tenha sido superior à EBM do controle. A suplementação orgânica obteve resultados inferiores em relação ao controle e ao substrato com suplementação mineral, sendo estatisticamente diferente destes (Tabela 6). A suplementação do substrato com solução mineral mostrou-se mais satisfatória, pois obteve um incremento na produção em relação ao controle sem ocasionar problemas com contaminantes, embora estes tratamentos não tenham diferido entre si estatisticamente.

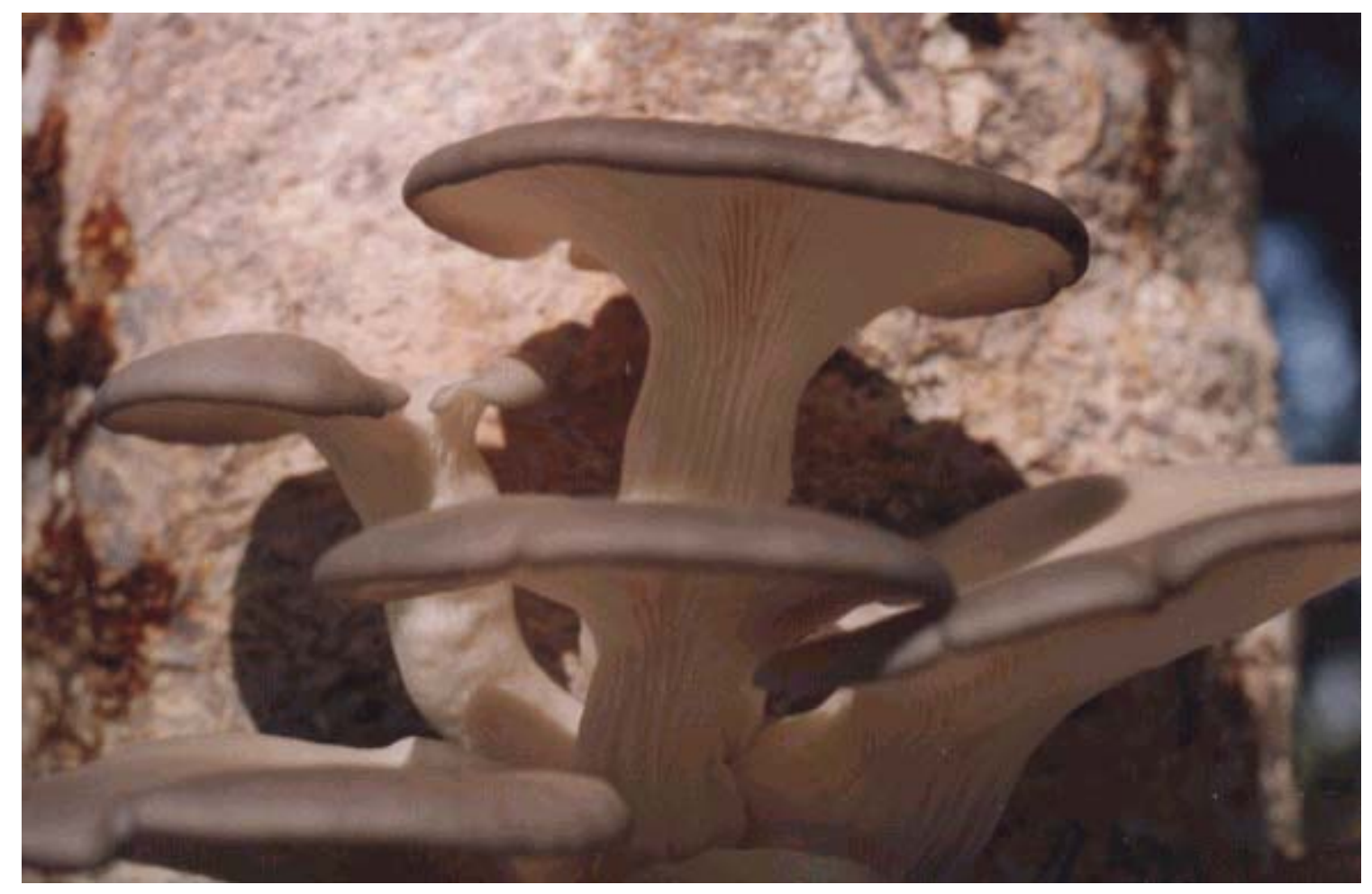

Figura 6 - Cogumelos Pleurotus sajor-caju em substrato lavado e suplementado com solução nutritiva. 
Tabela 5. Produção, contaminação e EB dos substratos lavado, lavado com suplementação orgânica e lavado com suplementação mineral.

\begin{tabular}{|c|c|c|c|c|c|c|}
\hline Trat. & $1^{\circ}$ fluxo (g) & $2^{\circ}$ fluxo $(\mathrm{g})$ & $3^{\circ}$ fluxo (g) & Contamin. & Peso (g) & EB\% \\
\hline C & 26,65 & 12,52 & 7,42 & ausente & 46,59 & 16,64 \\
\hline C & 29,83 & 18,31 & 10,70 & ausente & 58,84 & 21,01 \\
\hline C & 39,03 & 25,74 & 17,65 & ausente & 82,42 & 29,44 \\
\hline C & 32,33 & 35,92 & 19,30 & ausente & 87,55 & 31,27 \\
\hline C & 33,53 & 21,52 & 20,57 & ausente & 75,62 & 27,01 \\
\hline C & 32,82 & 25,92 & 20,15 & ausente & 78,89 & 28,18 \\
\hline C & 19,25 & 28,42 & 25,15 & ausente & 72,82 & 26,01 \\
\hline C & 27,60 & 15,73 & 23,12 & ausente & 66,45 & 23,73 \\
\hline C & 39,20 & 25,90 & 22,18 & ausente & 87,28 & 31,17 \\
\hline C & 36,18 & 27,36 & 25,57 & ausente & 89,11 & 31,83 \\
\hline $\mathrm{Q}$ & 19,86 & 13,92 & * & presente & 33,78 & 12,06 \\
\hline $\mathrm{Q}$ & 23,97 & 29,07 & * & presente & 53,04 & 18,94 \\
\hline $\mathrm{Q}$ & 19,98 & 15,28 & * & presente & 35,26 & 12,59 \\
\hline $\mathrm{Q}$ & 26,61 & 17,39 & * & presente & 44,00 & 15,71 \\
\hline $\mathrm{Q}$ & 24,95 & 10,93 & * & presente & 35,88 & 12,81 \\
\hline $\mathrm{Q}$ & 31,33 & 10,91 & * & presente & 42,24 & 15,09 \\
\hline $\mathrm{Q}$ & 32,37 & 7,52 & 5,92 & ausente & 45,81 & 16,36 \\
\hline $\mathrm{Q}$ & 17,75 & 12,57 & 3,35 & ausente & 33,67 & 12,03 \\
\hline $\mathrm{Q}$ & 36,98 & 11,97 & 5,92 & ausente & 54,87 & 19,60 \\
\hline $\mathrm{Q}$ & 34,33 & 17,12 & 8,54 & ausente & 59,99 & 21,43 \\
\hline$s$ & 27,83 & 32,42 & 26,02 & ausente & 86,27 & 30,81 \\
\hline $\mathrm{S}$ & 26,65 & 35,12 & 19,03 & ausente & 80,80 & 28,86 \\
\hline S & 35,92 & 29,01 & 30,95 & ausente & 95,88 & 34,24 \\
\hline S & 35,01 & 29,97 & 15,13 & ausente & 80,11 & 28,61 \\
\hline $\mathrm{S}$ & 31,59 & 32,72 & 25,10 & ausente & 89,41 & 31,93 \\
\hline $\mathrm{S}$ & 25,77 & 36,55 & 30,72 & ausente & 93,04 & 33,23 \\
\hline $\mathrm{S}$ & 25,93 & 37,12 & 15,92 & ausente & 78,97 & 28,20 \\
\hline S & 31,50 & 25,15 & 22,13 & ausente & 78,78 & 28,14 \\
\hline S & 22,44 & 37,14 & 22,17 & ausente & 81,75 & 29,20 \\
\hline $\mathrm{S}$ & 24,64 & 32,19 & 19,15 & ausente & 75,98 & 27,14 \\
\hline
\end{tabular}

* Interrupção da produção devido à contaminação do substrato.

$\mathrm{C}$ refere-se ao controle; $\mathrm{Q}$ à suplementação orgânica e $\mathrm{S}$ à suplementação mineral. 
Tabela 6. EBM dos substratos lavado, lavado com suplementação orgânica e lavado com suplementação mineral.

\begin{tabular}{ll}
\hline \multicolumn{1}{c}{ Tratamentos } & EBM (\%) \\
\hline Lavado com suplementação mineral & $30,035 \mathrm{a}$ \\
Lavado (controle) & $26,628 \mathrm{a}$ \\
Lavado com suplementação orgânica & $15,662 \mathrm{~b}$ \\
\hline
\end{tabular}

Nota: Valor de $\mathrm{F}=40,59 ; \mathrm{R}^{2}=0,75$

Médias seguidas da mesma letra não diferem entre si em nível de $5 \%$ de probabilidade através do Teste de Tukey.

\subsubsection{Contaminações}

A contaminação no substrato com suplementação orgânica ocorreu devido à presença da quirera de milho cozida, de forma que para a metodologia de lavagem do substrato a suplementação orgânica não respondeu satisfatoriamente. Foram observados focos de infecção ao redor dos grânulos de quirera espalhados no substrato, de cor arroxeada, indicando uma provável fermentação. A porcentagem de contaminação no substrato lavado com suplementação orgânica foi de $60 \%$, prejudicando sua produtividade e interrompendo sua produção após o segundo fluxo.

Baseado no Boletim Técnico 100 do IAC (1996) foi calculada a quantidade de nutrientes presentes em 20 e $200 \mathrm{~mL}$ de solução mineral, de acordo com os adubos solúveis que foram utilizados no preparo (Tabela 7 ). A solução mineral utilizada foi adaptada do cultivo de alface crespa hidropônica; as dosagens dos adubos utilizados foram aumentadas em 50 vezes, considerando que a solução seria acrescentada uma única vez, no meio do processo de miceliação do cogumelo no substrato. As dosagens utilizadas no processo de hidroponia são diminutas, uma vez que a solução circula constantemente pelos tubos e um excesso de sais poderia prejudicar a 
produção. Não existem dados disponíveis na literatura sobre a utilização de soluções para a suplementação de substratos sólidos no cultivo de Pleurotus sp. Desta forma, o aprimoramento da solução nutritiva é um interessante caminho para a produção de cogumelos, pois melhora a qualidade e quantidade de cogumelos, sem aumentar a contaminação.

Tabela 7. Garantia mínima em nutrientes da solução nutritiva.

\begin{tabular}{lll}
\hline Nutriente & Quantidade $(200 \mathrm{~mL})$ & Quantidade $(20 \mathrm{~mL})$ \\
\hline Nitrogênio (N) & $2,3 \mathrm{~g}$ & $0,23 \mathrm{~g}$ \\
Fósforo (P) & $0,3 \mathrm{~g}$ & $0,03 \mathrm{~g}$ \\
Potássio (K) & $1,83 \mathrm{~g}$ & $0,183 \mathrm{~g}$ \\
Cálcio (Ca) & $0,37 \mathrm{~g}$ & $0,037 \mathrm{~g}$ \\
Magnésio (Mg) & $0,63 \mathrm{~g}$ & $0,063 \mathrm{~g}$ \\
Enxofre (S) & $0,89 \mathrm{~g}$ & $0,089 \mathrm{~g}$ \\
Manganês (Mn) & $1,3 \mathrm{mg}$ & $0,13 \mathrm{mg}$ \\
Zinco (Zn) & $0,1 \mathrm{mg}$ & $0,01 \mathrm{mg}$ \\
Boro (B) & $0,16 \mathrm{mg}$ & $0,016 \mathrm{mg}$ \\
Cobre (Cu) & $0,026 \mathrm{mg}$ & $0,003 \mathrm{mg}$ \\
Molibdênio (Mo) & $0,078 \mathrm{mg}$ & $0,008 \mathrm{mg}$ \\
Sódio (Na) & $0,04 \mathrm{mg}$ & $0,004 \mathrm{mg}$ \\
Ferro EDTA (Fe) & $0,05 \mathrm{~mL}$ & $0,005 \mathrm{~mL}$ \\
\hline
\end{tabular}




\subsection{Análises físicas dos cogumelos}

\subsubsection{Peso}

Em relação à análise do peso, observou-se uma redução significativa no peso das bandejas entre os dias 0,5 e 10 após os tratamentos, apresentando médias de: 50,07g, 46,25 g e 40,64 g, respectivamente. O cogumelo apresenta uma alta taxa respiratória no período pós-colheita e sua umidade é geralmente de $85-90 \%$. Estes fatores contribuem significativamente para a redução da umidade do produto e conseqüentemente para a perda de peso. Entretanto, esta perda ao longo do armazenamento é citada por outros autores, estando dentro dos padrões registrados. Segundo Bano \& Rajarathnam (1988) a alta umidade dos cogumelos Pleurotus deixa-os predispostos à dessecação na temperatura ambiente. Nardim (1999) relatou que uma das consequências da perda de água por evaporação é o enrugamento do píleo, seguido de contração e enrijecimento, fatos observados no controle. A variação de peso entre os tratamentos foi praticamente uniforme ao longo do período e não diferiu entre os mesmos, ou seja, os tratamentos não influenciaram em uma maior ou menor perda de peso, sendo portanto indiferente o tratamento utilizado para esta avaliação em especial (Figura 7). 


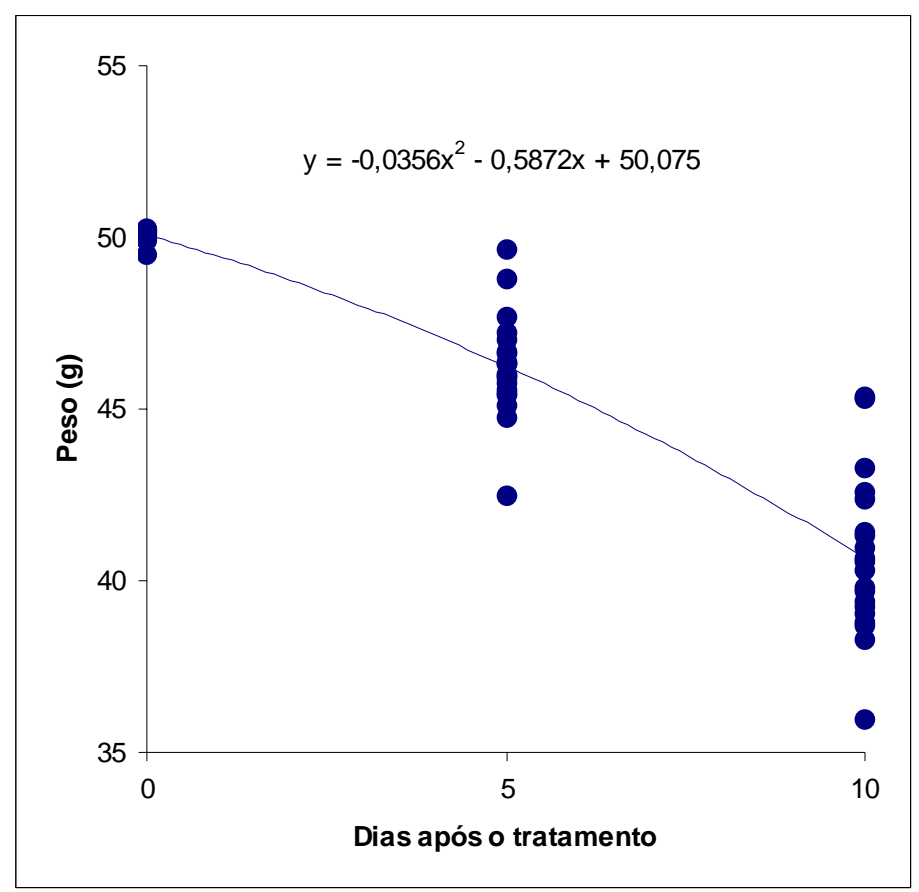

Figura 7 - Peso das bandejas durante o período de armazenamento.

\subsubsection{Firmeza}

Através da comparação das médias obtidas nos diferentes tratamentos durante o período de avaliação (Tabela 8), observou-se que para o controle houve diferença significativa na redução da firmeza entre os dias 0 $(0,49 \mathrm{~N})$ e $5(0,34 \mathrm{~N})$; entre os dias $5(0,34 \mathrm{~N})$ e $10(0,33 \mathrm{~N})$ não houve diferença. Para o tratamento com peróxido de hidrogênio, também ocorreu diferença significativa entre os dias $0(0,48 \mathrm{~N})$ e $5(0,33 \mathrm{~N})$, sendo que entre os dias $5(0,33 \mathrm{~N})$ e $10(0,34 \mathrm{~N})$ não ocorreu modificação na firmeza. No tratamento com água destilada, não ocorreu diferença entre os dias $0(0,44 \mathrm{~N})$ e $5(0,36 \mathrm{~N})$ e entre os dias $5(0,36 \mathrm{~N})$ e $10(0,33 \mathrm{~N})$, porém entre os dias 0 e 10 a 
diferença foi significativa. Já no tratamento com ácido cítrico, não ocorreu diferença ao longo do período de avaliação devido a redução da firmeza logo após a imersão dos cogumelos na solução. Desta forma verificou-se que, exceto para o tratamento com ácido cítrico, houve redução da firmeza dos cogumelos ao longo do período de armazenamento. Quanto à avaliação entre os tratamentos nos dias 0,5 e 10, pode-se dizer que somente o dia 0 apresentou diferença significativa entre o controle e os demais tratamentos, conforme a Tabela 8.

Tabela 8. Firmeza dos cogumelos tratados com ácido cítrico, peróxido de hidrogênio, água destilada e controle durante o período de armazenamento.

\begin{tabular}{llll}
\hline Dias & 0 & 5 & 10 \\
\hline Controle & $0,49 \mathrm{Aa}$ & $0,34 \mathrm{Ab}$ & $0,33 \mathrm{Ab}$ \\
Peróx. Hidrog. & $0,48 \mathrm{Aa}$ & $0,33 \mathrm{Ab}$ & $0,34 \mathrm{Ab}$ \\
Água destilada & $0,44 \mathrm{ABa}$ & $0,36 \mathrm{Aab}$ & $0,33 \mathrm{Ab}$ \\
Ácido Cítrico & $0,32 \mathrm{Ba}$ & $0,33 \mathrm{Aa}$ & $0,30 \mathrm{Aa}$ \\
\hline
\end{tabular}

Nota: Letras maiúsculas distintas diferem ao nível de $5 \%$ de probabilidade entre os tratamentos; letras minúsculas distintas diferem ao nível de $5 \%$ de probabilidade entre os dias, através do Teste de Tukey.

Através da Figura 8 observou-se que o tratamento com ácido cítrico apresentou redução na firmeza dos cogumelos desde a primeira avaliação, logo após a imersão dos cogumelos na solução, indicando ser este o tratamento menos apropriado para a manutenção da firmeza dos cogumelos. Este resultado pode ter ocorrido devido a quantidade de ácido cítrico utilizado na solução ou devido à fragilidade do Pleurotus sajor-caju, uma vez que o Brennan et al. (2000) utilizaram a mesma solução em Agaricus bisporus fatiados. 


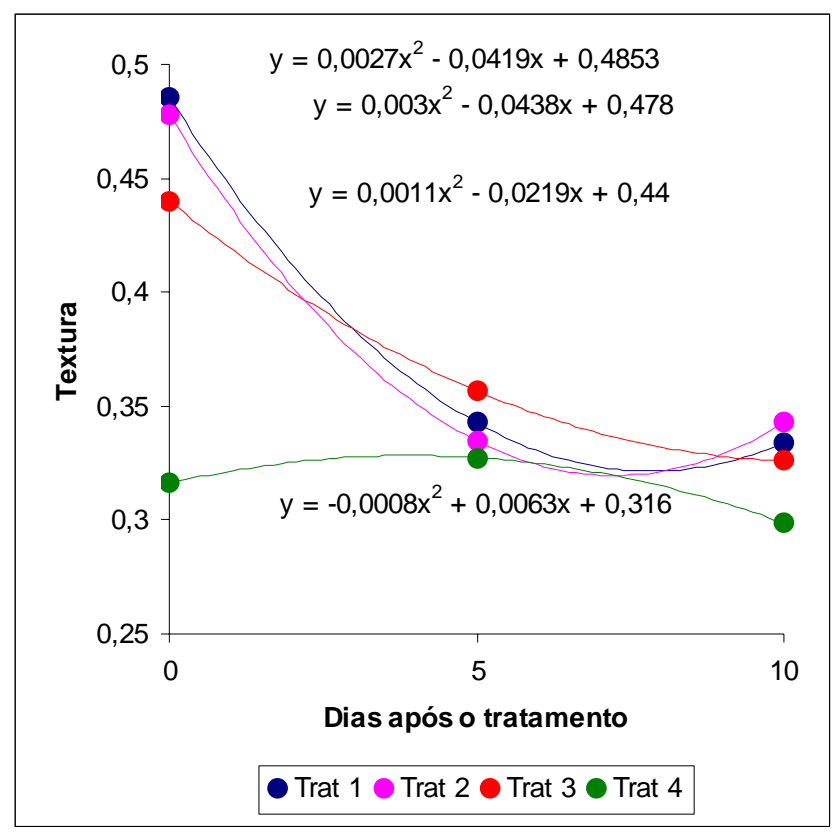

Figura 8 - Firmeza dos cogumelos durante o período de armazenamento.

- Tratamento 1: Controle ( $\left.y=0,0027 x^{2}-0,0419 x+0,4853\right)$

- Tratamento 2: Solução de peróxido de hidrogênio (y =0,003x $x^{2}-0,0438 x+$ $0,478)$

- Tratamento 3: Água destilada $\left(y=0,0011 x^{2}-0,0219 x+0,44\right)$

- Tratamento 4 : Solução com ácido cítrico $\left(y=0,0008 x^{2}+0,0063 x+0,316\right)$ 


\subsubsection{Cor}

\subsubsection{Valor $L^{*}$}

Através da comparação das médias obtidas dos diferentes tratamentos observou-se que para o controle não houve diferença significativa na luminosidade $\left(L^{\star}\right)$ apresentada pelos cogumelos ao longo do período de avaliação (Tabela 9). O mesmo resultado foi encontrado nos cogumelos tratados com peróxido de hidrogênio e água destilada; entretanto houve redução na luminosidade dos cogumelos tratados com ácido cítrico entre os dias $0(74,12)$ e $5(66,99)$, quando apresentaram um escurecimento. Constatouse que, exceto no tratamento com ácido cítrico, os demais não sofreram escurecimento durante o experimento. Em relação aos tratamentos, observouse que o controle $(82,45)$ foi significativamente diferente dos tratamentos com peróxido de hidrogênio $(66,71)$, água destilada $(72,32)$ e ácido cítrico $(74,12)$ no dia 0 . $O$ valor $L^{*}$ dos cogumelos tratados com ácido cítrico e água destilada também diferiu no dia 0 do tratado com peróxido de hidrogênio. No dia 5 , houve diferença significativa entre o controle e os demais, que manteve-se no dia 10. Pode-se concluir que logo após a imersão dos cogumelos nas diferentes soluções houve significativa diferença na luminosidade, com o escurecimento dos mesmos; entretanto, esta diferença quase desapareceu nas avaliações realizadas nos dias 5 e 10, em função dos cogumelos terem escurecido de maneira uniforme, com exceção do controle. Através da Figura 9, observou-se que a imersão dos cogumelos nas diferentes soluções propiciou o escurecimento dos mesmos, não sendo este um elemento desejável para o cogumelo fresco. 
Tabela 9. Luminosidade $\left(L^{*}\right)$ dos cogumelos tratados com ácido cítrico, peróxido de hidrogênio, água destilada e controle durante o período de armazenamento.

\begin{tabular}{llll}
\hline Dias & 0 & 5 & 10 \\
\hline Controle & $82,45 \mathrm{Aa}$ & $79,09 \mathrm{Aa}$ & $79,48 \mathrm{Aa}$ \\
Peróx. Hidrog. & $66,71 \mathrm{Ca}$ & $65,65 \mathrm{Ba}$ & $70,27 \mathrm{Ba}$ \\
Água destilada & $72,32 \mathrm{BCa}$ & $70,53 \mathrm{Ba}$ & $73,05 \mathrm{Ba}$ \\
Ácido cítrico & $74,12 \mathrm{Ba}$ & $66,99 \mathrm{Bb}$ & $70,79 \mathrm{Bab}$ \\
\hline
\end{tabular}

Nota: Letras maiúsculas distintas diferem ao nível de $5 \%$ de probabilidade entre os tratamentos; letras minúsculas distintas diferem ao nível de $5 \%$ de probabilidade entre os dias, através do Teste de Tukey.

De acordo com Burton et al. (2000), os valores de L* registrados para cogumelos frescos Agaricus bisporus variaram de 90 a 95; entretanto, estes valores caíram para 70 a 65 após 5 dias de armazenamento sob refrigeração. Em relação ao cogumelo Pleurotus sajor-caju, os "champignons" apresentaram valores de $L^{*}$ mais elevados, por terem uma coloração próxima do branco. $\mathrm{O}$ Pleurotus sp. é naturalmente mais escuro, com coloração marrom-acinzentada logo após a colheita. 


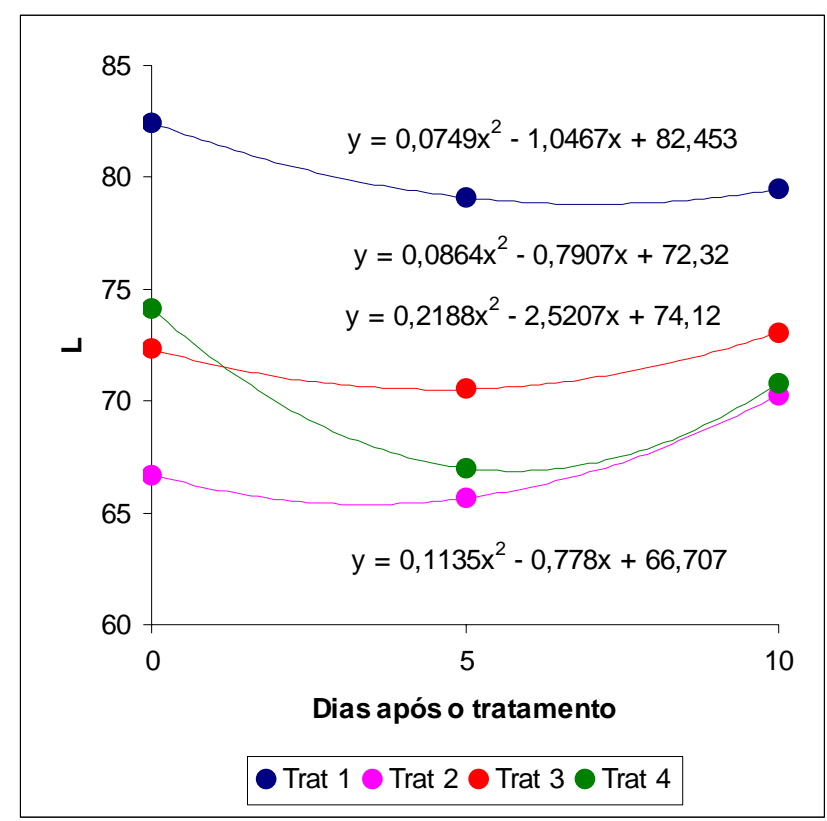

Figura 9 - Luminosidade $\left(L^{*}\right)$ dos cogumelos durante o período de armazenamento.

- Tratamento 1: Controle $\left(y=0,0749 x^{2}-1,0467 x+82,453\right)$

- Tratamento 2: Solução de peróxido de hidrogênio ( $y=0,1135 x^{2}-0,778 x+$ $66,707)$

- Tratamento 3: Água destilada $\left(y=0,0864 x^{2}-0,7907 x+72,32\right)$

- Tratamento 4 : Solução com ácido cítrico $\left(y=0,2188 x^{2}-2,5207 x+74,12\right)$ 


\subsubsection{Valor $\mathrm{a}^{*}$}

Através da comparação das médias obtidas nos diferentes tratamentos durante o período de avaliação, observou-se que o controle apresentou diferença significativa somente no dia $5(-1,19)$, em relação aos dias $0(-0,64)$ e $10(-0,02)$, os quais não diferiram entre si. $O$ tratamento com peróxido de hidrogênio, apresentou diferença significativa somente no dia 10 ($0,06)$ em relação aos dias $0(-1,07)$ e $5(-1,22)$, os quais não diferiram entre si. Para o tratamento com água destilada, houve diferença significativa somente no dia $5(-1,56)$ em relação aos dias $0(-0,90)$ e $10(-0,20)$, que não diferiram entre si. Para o tratamento com ácido cítrico, não ocorreram diferenças significativas entre os períodos de avaliação, sendo os valores médios registrados de: 0 (1,57), $5(-1,61)$ e $10(-1,07)$. Através dos valores $a^{\star}$ no dia 5 observou-se para todos os tratamentos um aumento na coloração para o verde, sendo que no dia 10 ocorreu uma regressão deste valor, com valores mais próximos de zero (Tabela 10). Em relação à diferença entre os tratamentos observou-se que somente no tratamento com ácido cítrico no dia 0 houve diferença significativa, com uma mudança na coloração dos cogumelos logo após sua imersão na solução, tornando-os levemente verde-azulados. Entretanto, esta diferença desapareceu nas outras avaliações, de forma que o tratamento com ácido cítrico passou a não apresentar diferença significativa com os demais. 
Tabela 10. Valor $a^{\star}$ dos cogumelos tratados com ácido cítrico, peróxido de hidrogênio, água destilada e controle durante o período de armazenamento.

\begin{tabular}{llll}
\hline Dias & 0 & 5 & 10 \\
\hline Controle & $-0,64 \mathrm{Aa}$ & $-1,19 \mathrm{Ab}$ & $-0,02 \mathrm{Aa}$ \\
Peróx. Hidrog. & $-1,07 \mathrm{Ab}$ & $-1,22 \mathrm{Ab}$ & $-0,06 \mathrm{Aa}$ \\
Água destilada & $-0,90 \mathrm{Aa}$ & $-1,56 \mathrm{Ab}$ & $-0,20 \mathrm{Aa}$ \\
Ácido cítrico & $-1,57 \mathrm{Ba}$ & $-1,61 \mathrm{Aa}$ & $-1,07 \mathrm{Aa}$ \\
\hline
\end{tabular}

Nota: Letras maiúsculas distintas diferem ao nível de $5 \%$ de probabilidade entre os tratamentos; letras minúsculas distintas diferem ao nível de $5 \%$ de probabilidade entre os dias, através do Teste de Tukey.

Observando-se a Figura 10, percebe-se uma pequena tendência em todos os tratamentos a uma tonalização para o verde na avaliação do dia 5. Esta tonalização desapareceu na avaliação do dia 10. Entretanto a maioria dos valores de $a^{*}$ registrados estavam muito próximos do zero na escala do disco de cores, o que implicou em uma tonalidade realmente próxima do cinza claro ou neutro, que é característico do cogumelo Pleurotus sajor-caju. 


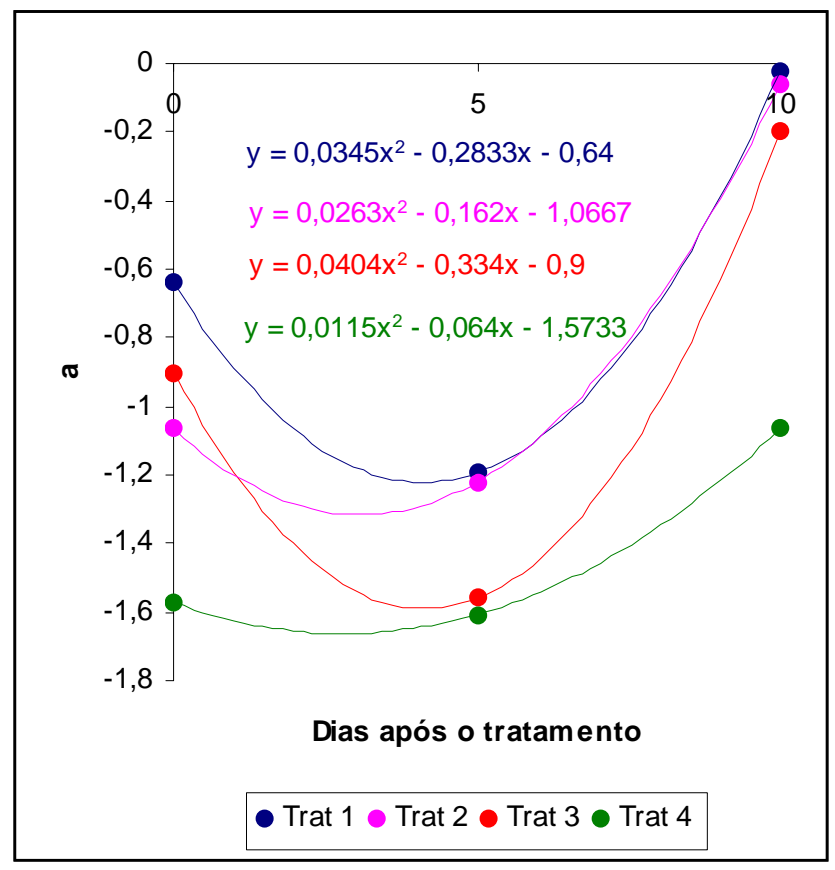

Figura 10 - Valor a* dos cogumelos durante o período de armazenamento.

- Tratamento 1: Controle $\left(y=0,0345 x^{2}-0,2833 x-0,64\right)$

- Tratamento 2: Solução de peróxido de hidrogênio ( $y=0,0263 x^{2}-0,162 x-$ 1,0667)

- Tratamento 3: Água destilada $\left(y=0,0404 x^{2}-0,334 x-0,9\right)$

- Tratamento 4 : Solução com ácido cítrico $\left(y=0,0115 x^{2}-0,064 x-1,5733\right)$ 


\subsubsection{Valor $b^{*}$}

Através da comparação das médias obtidas nos diferentes tratamentos durante o período de avaliação, observou-se que à exceção do controle, todos os tratamentos apresentaram diferença significativa entre os períodos de armazenamento 0, 5 e 10 dias (Tabela 11). Para o controle, ocorreu diferença significativa somente entre os dias 0 e 5 , sendo que os dias 5 e 10 não diferiram entre si. Os valores variaram de 6,95 a 7,97 no dia 0; 12,56 a 14,99 no dia 5 e 16,63 a 17,65 no dia 10. Burton et al. (2000) registrou valores de $b^{\star}$ para Agaricus bisporus frescos entre 6 e 10, indicando um leve amarelecimento deste cogumelo.

Neste trabalho, a principal diferença na coloração foi o amarelecimento do Pleurotus, registrado pelo aumento do valor b* independentemente da solução utilizada, registrados na Tabela 11 e Figura 11. Este amarelecimento ocorre na maioria dos cogumelos de coloração clara e deve-se principalmente a ação da enzima tirosinase, responsável pelo processo de escurecimento enzimático através da formação das melaninas. Os cogumelos mais escuros, como o shiitake (Lentinula edodes) adquirem uma tonalidade de marrom escuro devido à ação da mesma enzima.

Concluiu-se que independentemente da solução utilizada, todos os tratamentos adquiriram uma tonalidade amarelada ao final do experimento, ou seja, nenhuma das soluções utilizadas contribuiu para a preservação da tonalidade original do cogumelo levemente marrom-acinzentada, logo após sua colheita. 
Tabela 11. Valor $b^{\star}$ dos cogumelos tratados com ácido cítrico, peróxido de hidrogênio, água destilada e controle durante o período de armazenamento.

\begin{tabular}{llll}
\hline Dias & 0 & 5 & 10 \\
\hline Controle & $7,77 \mathrm{Ab}$ & $14,99 \mathrm{Aa}$ & $16,63 \mathrm{Aa}$ \\
Peróx. Hidrog. & $7,06 \mathrm{Ac}$ & $14,21 \mathrm{Ab}$ & $17,67 \mathrm{Aa}$ \\
Água destilada & $6,95 \mathrm{Ac}$ & $14,81 \mathrm{Ab}$ & $17,65 \mathrm{Aa}$ \\
Ácido cítrico & $7,97 \mathrm{Ac}$ & $12,56 \mathrm{Ab}$ & $17,35 \mathrm{Aa}$ \\
\hline
\end{tabular}

Nota: Letras maiúsculas distintas diferem ao nível de $5 \%$ de probabilidade entre os tratamentos; letras minúsculas distintas diferem ao nível de $5 \%$ de probabilidade entre os dias, através do Teste de Tukey.

\subsubsection{Considerações Gerais}

Observou-se que os cogumelos Pleurotus sajor-caju seguiram basicamente um mesmo padrão em relação à mudança na coloração, peso e firmeza, com exceção do tratamento com ácido cítrico, que revelou-se o menos apropriado. Os tratamentos com água destilada e solução de peróxido de hidrogênio foram semelhantes entre si, porém com resultados aquém dos desejados. O controle foi o que melhor se manteve ao longo do período de armazenamento, nos quesitos já citados. Quanto à coloração, medida em valores de $L^{*}, a^{*} e b^{\star}$, os cogumelos seguiram um padrão conforme observado na Figura 12, ou seja, todos os cogumelos sofreram perda de luminosidade e amareleceram com o passar do tempo. A firmeza e o peso dos cogumelos também foram reduzidos, com a perda do frescor e a turgidez das "pétalas". A distribuição ao longo do período pode ser mais facilmente observada através da Figura 13, onde mostrou-se a distribuição das repetições nos dias 0, 5 e 10. 


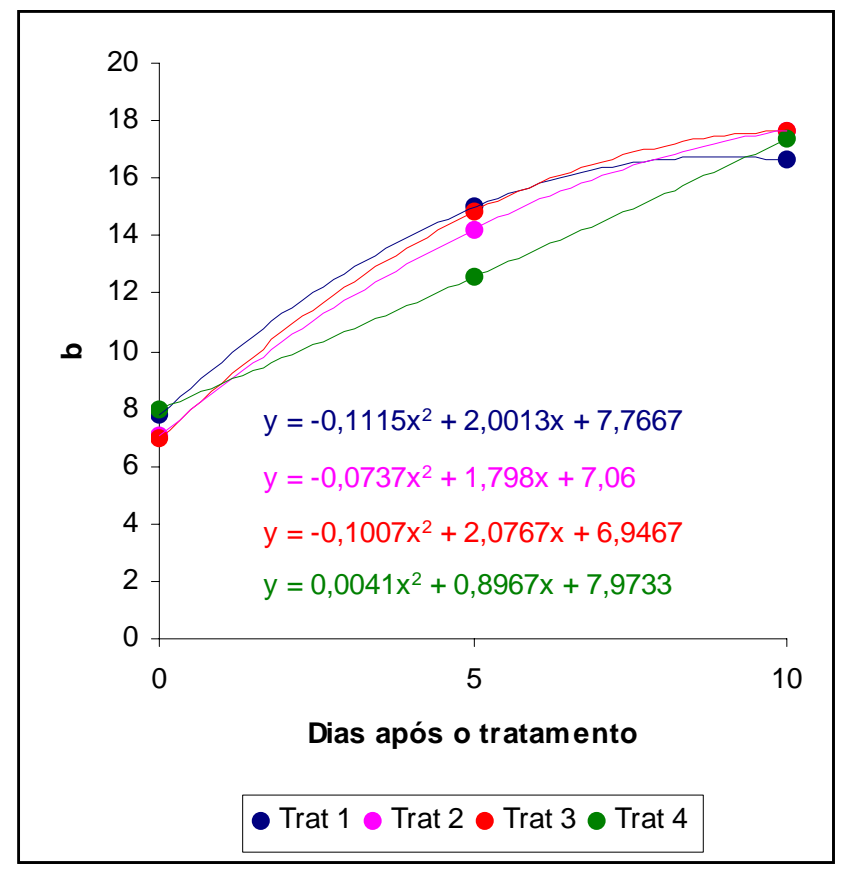

Figura 11 - Valor b* dos cogumelos durante o período de armazenamento.

- Tratamento 1: Controle $\left(y=-0,1115 x^{2}+2,0013 x+7,7667\right)$

- Tratamento 2: Solução de peróxido de hidrogênio $\left(y=-0,0737 x^{2}+1,798 x+\right.$ $7,06)$

- Tratamento 3: Água destilada $\left(y=-0,1007 x^{2}+2,0767 x+6,9467\right)$

- Tratamento 4 : Solução com ácido cítrico $\left(y=-0,0041 x^{2}+0,8967 x+7,9733\right)$ 


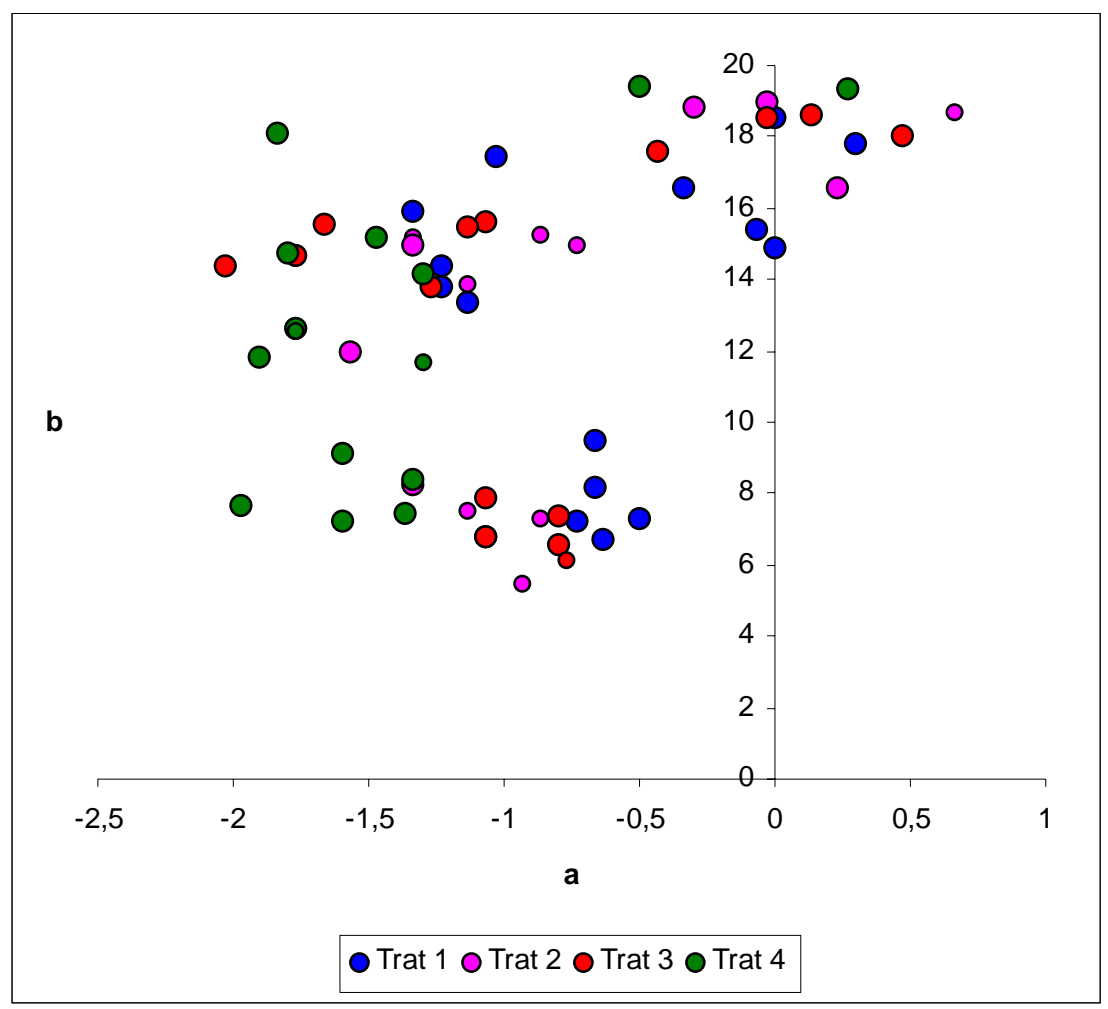

Figura 12 - Distribuição dos tratamentos durante o período de armazenamento, em relação aos valores $a^{*} e b^{*}$.

- Tratamento 1: Controle

- Tratamento 2: Solução de peróxido de hidrogênio

- Tratamento 3: Água destilada

- Tratamento 4 : Solução com ácido cítrico 


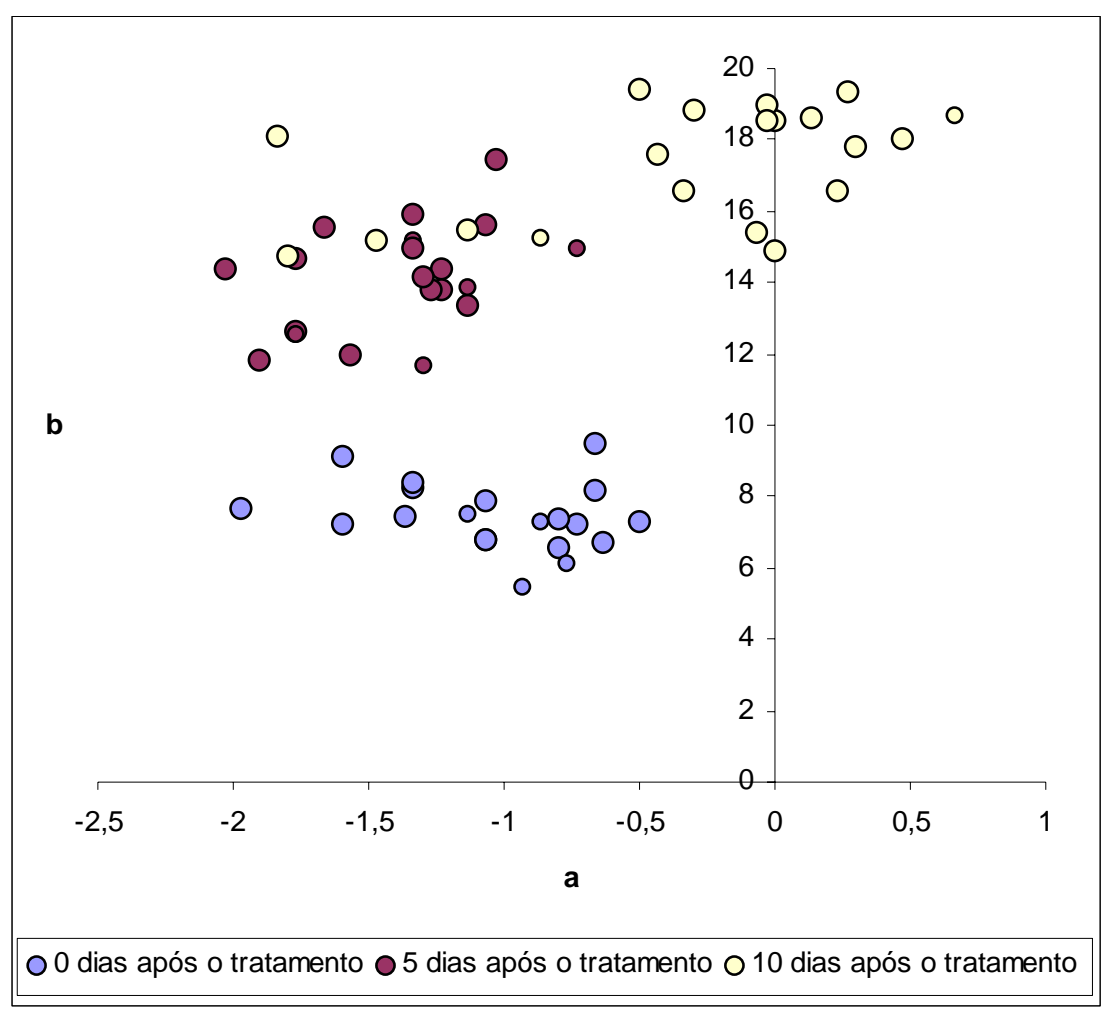

Figura 13 - Distribuição das repetições durante o período de armazenamento,em relação aos valores $a^{\star}$ e b*. 
Através de avaliação visual realizada em laboratório no último dia do experimento, observou-se que nos cogumelos tratados com peróxido de hidrogênio, água destilada e controle ocorreu uma colonização superficial branca em partes do cogumelo, acompanhando o sentido das lamelas, de aspecto aveludado. A colonização branca encontrada no final do período de armazenamento foi proveniente da miceliação do próprio Pleurotus sajor-caju. Normalmente, em cogumelos com 7 a 10 dias após a colheita, esta miceliação acontece, mesmo estando em condições de refrigeração. Segundo Bano \& Rajarathnam (1988), após 8 a 10 dias a $2^{\circ} \mathrm{C}$ desenvolveu-se sobre a superfície do píleo de Pleurotus ostreatus um micélio branco, com aspecto lanuginoso, proveniente do próprio cogumelo, sendo este um fator limitante para a comercialização dos cogumelos frescos. Quanto à turgidez dos cogumelos, os tratamentos com água destilada e peróxido de hidrogênio obtiveram os melhores resultados, pois o controle apresentou aspecto um pouco ressecado e o tratamento com ácido cítrico um aspecto melado e brilhante.

Odor de caju foi observado no controle e no tratamento com água destilada, característico da espécie, enquanto que o tratamento com peróxido de hidrogênio apresentou um odor estranho, juntamente com uma aparência de "cozido". O cogumelo tratado com ácido cítrico apresentou desestruturação evidente, contaminações por outros fungos e bactérias e mau cheiro no final do experimento. 


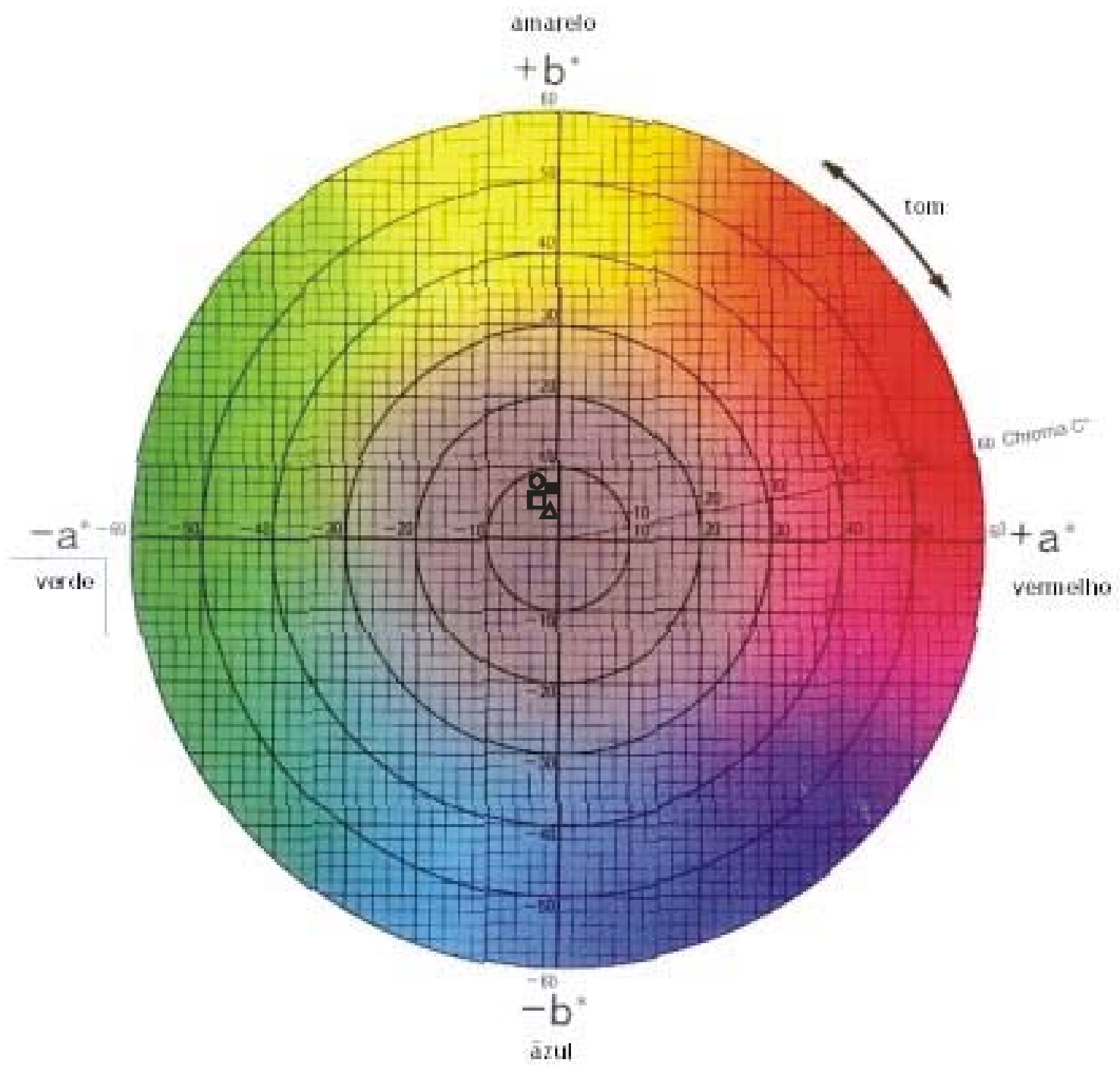

Figura 14 - Coloração dos cogumelos no dia 0, representada pelos valores $\mathrm{a}^{\star} \mathrm{e}$ b* para o controle $(\square)$, para o tratamento com solução de ácido cítrico (0), para o tratamento com solução de peróxido de hidrogênio $(\triangle)$ e para água destilada $(\boldsymbol{\square})$. 


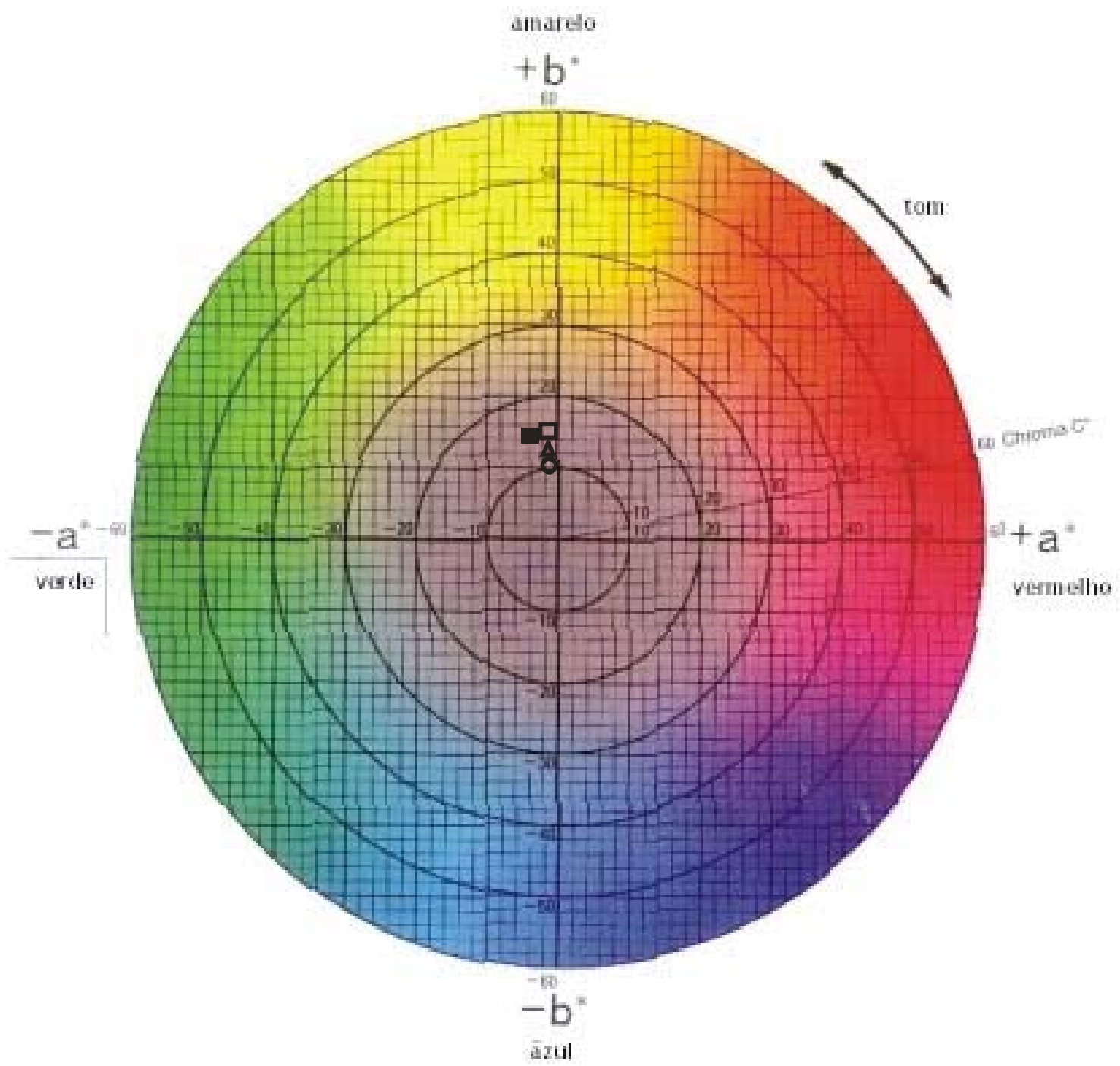

Figura 15 - Coloração dos cogumelos no dia 5, representada pelos valores $\mathrm{a}^{*} \mathrm{e}$ $b^{\star}$, para o controle $(\square)$, para o tratamento com solução de ácido cítrico (0), para o tratamento com solução de peróxido de hidrogênio $(\triangle)$ e para água destilada $(\boldsymbol{\square})$. 


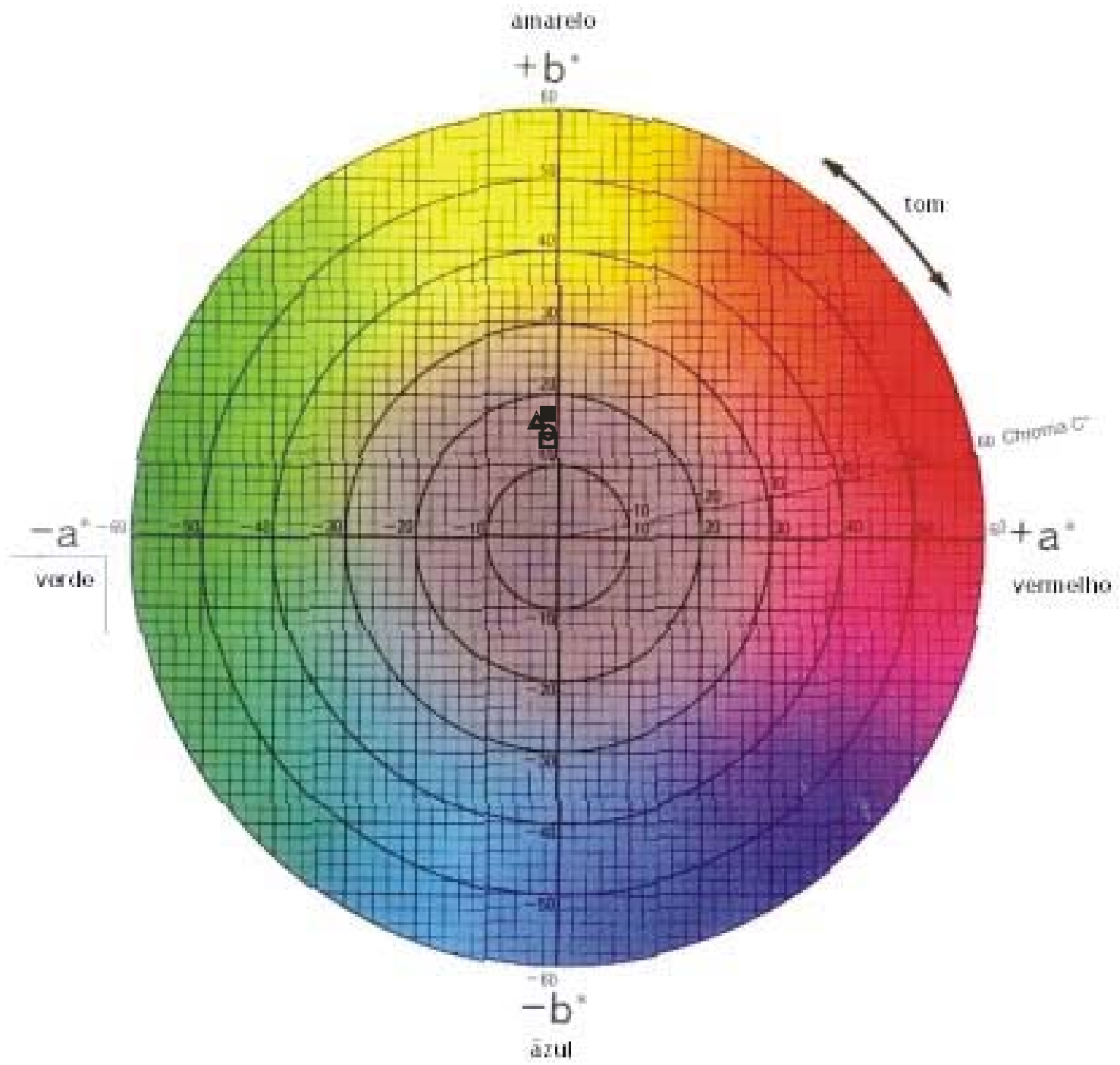

Figura 16 - Coloração dos cogumelos no dia 10, representada pelos valores $\mathrm{a}^{*}$ e $b^{\star}$, para o controle $(\square)$, para o tratamento com solução de ácido cítrico (0), para o tratamento com solução de peróxido de hidrogênio $(\triangle)$ e para água destilada $(\boldsymbol{\square})$. 


\section{CONCLUSÕES}

De acordo com os resultados obtidos e analisados, podemos concluir que:

1 A lavagem simples do bagaço fresco de cana-de-açúcar para a obtenção de substrato para a produção do cogumelo Pleurotus sajor-caju pode substituir o processo de pasteurização comumente utilizado neste cultivo, com vantagens econômicas;

2 A suplementação mineral do substrato lavado do bagaço de cana-deaçúcar com solução nutritiva pode ser utilizada para a complementação do mesmo, melhorando a produtividade e a qualidade dos cogumelos sem aumentar a contaminação do substrato;

3 A utilização das diferentes soluções para o prolongamento da vida útil do Pleurotus sajor-caju não apresentou resultados eficientes para os atributos firmeza e coloração, considerados importantes na aceitação pelo consumidor, devendo-se portanto estudar outros métodos ou diluições para a conservação do cogumelo fresco. 


\section{REFERÊNCIAS BIBLIOGRÁFICAS}

ABE, E.; EIRA, A.F.; MINHONI, M.T.A. Relações entre temperatura de pasteurização e contaminação do composto durante o cultivo de Pleurotus ostreatus (Jacquim Fries) Kummer. Científica, v.20, n.2, p.423-433, 1992.

ALEXOPOULOS, C.J.; BLACKWELL, C.W.; MINS, C.P. Introductory Mycology. New York: John Wiley \& Sons Inc., 1998. 868p.

AVIDOS, M.F.D. Cogumelos comestíveis: maior produtividade e menores custos. A Lavoura, v.99, n.620, p.18-19, 1997.

BAHUKHANDI, D.; MUNJAL, R.L. Cultivation of Pleurotus species on different agricultural residues. Indian Phytopathology, v.42, n.4, p.492-495, 1989.

BALASUBRAMANYA, R.H.; KATHE, A. An inexpensive pretreatment of cellulosic materials for growing edible oyster mushrooms. Bioresource Technology, v.57, p.303-305, 1996.

BANO, Z.; RAJARATHNAM, S. Pleurotus mushrooms: Part II. Chemical composition, preservation and role an human food. Critical Reviews in Food Science and Nutrition, v.27, n.2, p.87-158, 1988. 
BARDEN, C.L.; BEELMAN, R.B.; BARTLEM, C.E.; SCHISLER, L.C. The effect of calcium chloride added to the irrigation water on quality and shelf life of harvested mushrooms. Journal of Food Protection, v.53, n.9, p.759-769, 1990.

BEUX, M.R.; SOCCOL, C.R. Cultivo do fungo comestível Lentinula edodes em resíduos agroindustriais do Paraná através do uso de fermentação no estado sólido. Boletim do Centro de Pesquisa e Processamento de Alimentos, v.14, n.1, p.11-24, 1996.

BISARIA, R.; MADAN, M.; BISARIA, V.S. Biological efficiency and nutritive value of Pleurotus sajor-caju cultivated on different agro-wastes. Biological Wastes, v.19, n.2, p.239-255, 1987.

BISARIA, R.; MADAN, M.; VASUDEVAN, P.; BISARIA, N.S. Effect of variation in size of containers on yield of Pleurotus sajor-caju. Biological Wastes, v.30, n.1, p.149-152, 1989.

BISARIA, R.; MADAN, M.; VASUDEVAN, P. Utilisation of agro-residues as animal feed through bioconversion. Bioresource Technology, v.59, p.5-8, 1997.

BONONI, V.L. Alimenta e não engorda. A Granja, n.441, p.48-50, 1984.

BONONI, V.L.; TRUFEM, S.F.B. Cogumelos comestíveis. São Paulo: Editora Ícone, 1985. 85p.

BONONI, V.L.; CAPELARI, M.; MAZIERO, R.; TRUFEM, S.F.B. Cultivo de cogumelos comestíveis. São Paulo: Ícone, 1995. 206p. 
BORGES, M.F.; BRANDÃO, S.C.C.; PINHEIRO, A.J. Efeito bactericida do peróxido de hidrogênio sobre Salmonella spp. em leite destinado à fabricação de queijos. Revista de Microbiologia, v.20, n.2, p.145-149, 1989.

BRASIL. Ministério da Saúde. Divisão Nacional de Vigilância Sanitária de Alimentos. Portaria $n^{\circ} 12$, de 24 de julho de 1978. In: ASSOCIAÇÃO BRASILEIRA DAS INDÚSTRIAS DE ALIMENTAÇÃO. Compêndio da legislação de alimentos. São Paulo: ABIA, 1987. v.1A.

BRENNAN, M.; LEPORT, G.; PULVIRENTI, A. The effect of sodium metabissulphite on the whiteness and keeping quality of sliced mushroom. Lebensmittel-Wissenschaft \& Technologie, v.32, n.3, p.460-463, 1999.

BRENNAN, M.; LEPORT, G.; GORMLEY, R. Post-harvest treatment with citric acid or hydrogen peroxide to extend the shelf life of fresh sliced mushrooms. Lebensmittel-Wissenschaft \& Technologie, v.33, n.2, p.285-289, 2000.

BURTON, K.S. The effects of pre and post harvest development on mushroom tyrosinase. Journal of Horticultural Science, v.63, n.2, p.255-260, 1980.

BURTON, K.S.; SREENIVASAPRASAD, S.; EASTWOOD, D.; RAMA, T.; BEECHER, T.; MOLLOY, S. The science of mushroom quality. Mushroom Science, v.15, part. II, p.715-720, 2000.

BUSWELL, J.A.; CHANG, S.T. Edible mushrooms: attributes and aplications. In: CHANG, S.T.; BUSWELL, J.A.; MILES, P.G. Genetics and breeding of edible mushrooms. Amsterdam: Gordon and Breach Science Publishers, 1993. cap.15, p.306-318. 
COMPANHIA DE ENTREPOSTOS E ARMAZÉNS GERAIS DE SÃO PAULO CEAGESP. Boletim mensal: dados estatísticos relativos aos produtos hortigranjeiros e pescado afluídos ao ETSP. São Paulo, 1998. 110p.

CHANG, S.T. Mushrooms as human food. Bioscience, v.30, n.6, p.399-401, 1980.

CHANG, S.T.; LAU, O.W.; CHO, K.Y. The cultivation and nutritional value of Pleurotus sajor-caju. European Journal of Applied Microbiology and Biotechnology, v.12, p.58-62, 1981.

CHANG, S.T.; MILES, P.G. A new look at cultivated mushrooms. Bioscience, v.34, n.6, p.358-362, 1984.

CHIU, S.W.; CHAN, Y.H.; CHEUNG, K.T.; MOORE, D. Cadmium and manganese in contrast to calcium reduce yield and nutritional values of the edible mushroom Pleurotus pulmonarius. Mycological Research, v.102, n.4, p.449-457, 1998.

COLAUTO, N.B.; EIRA, A.F. Efeito de recipientes de contenção do substrato na distribuição da produção de Pleurotus sajor-caju (Fr.) Singer. Energia na Agricultura, v.10, n.2, p.19-28, 1995.

COSKUNER, Y.; OZDEMIR, Y. Acid and EDTA blanching effects on the essential element content of mushrooms (Agaricus bisporus). Journal of the Science of Food and Agriculture, v.80, p.2074-2076, 2000.

DHANDA, S.; SODHI, H.S.; PHUTELA, R.P. Nutrition and yield evaluation of oyster mushroom Pleurotus species. Indian Journal of Nutrition and Dietetics, v.33, n.11, p.275-278, 1996. 
FAO. Hongos comestibles y sus productos. Codex Alimentarius: norma general del codex para los hongos comestibles y sus productos. Genebra: Joint FAO, Who Codex Alimentarius Commission, 1995. v.5, p.39-52.

FELINTO, A.S. Cultivo de cogumelos comestíveis do gênero Pleurotus spp. em resíduos agroindustriais. Piracicaba, 1999. 123p. Dissertação (Mestrado) - Escola Superior de Agricultura "Luiz de Queiroz", Universidade de São Paulo.

FERREIRA, J.E.F. Produção de cogumelos. São Paulo: Editora Agropecuária, 1998. 136p.

FLEGG, P. Mushrooms, mineral elements and a new idea. Mushroom Journal, v.12, n.575, p.15-16, 1991.

FURLAN, F.; CHURATA-MASCA, M.G.C.; CARVALHO, R. de; BIANCHI, M.L.P. Valor nutritivo e conteúdo em fibra do cogumelo shiitake cultivado no Brasil. Horticultura Brasileira, v.12, n.1, p.80, 1994.

GOMEZ, R.J.H.C. Cultivo submerso de Pleurotus ostreatus em bagaço de cana-de-açúcar. Arquivos de Biologia e Tecnologia, v.33, n.3, p.701715, 1990.

GORMLEY, R. Chill storage of mushrooms. Journal of the Science of Food and Agriculture, v.26, n.2, p.401-411, 1975.

GROGAN, H.M.; SCRUBY, A.; HARVEY, L. Moulds in spawn-run compost and their effect on mushroom production. Mushroom Science, v.15, part II, p.609-615, 2000. 
INSTITUTO AGRONÔMICO DE CAMPINAS. Recomendações de adubação e calagem. Campinas: Terra Viva, 1996. 134p. (IAC. Boletim técnico, 100)

JORGE, N.; CHAVES, J.B.P. Avaliação sensorial de cogumelos (Agaricus bisporus) desidratados sob diferentes condições de secagem e armazenagem. Alimentos e Nutrição, v.4, p.65-78, 1992.

KÜES, U.; LIU, Y. Fruiting bosy production in basidiomycetes. Applied Microbiology and Biotechnology, v.54, n.2, p.141-152, 2000.

KURTZMAN, R.H. Nitrogen fixation by Pleurotus. Mushroom Science, v.10, n.1, p.427, 1978.

KUYPER, L.; WEINERT, I.A.G.; Mc GILL, A.E.J. The effect of modified atmosphere packaging and addition of calcium hypochlorite on the atmosphere composition, colour and microbial quality of mushrooms. Lebensmittel-Wissenschaft \& Technologie, v.26, n.5, p.14-20, 1993.

MACAYA-LIZANO, A.V. Cultivo de Pleurotus ostreatus y especies afines (Fungi: Pleurotaceae) sobre medios naturales semi-esteriles. Revista de Biologia Tropical, v.36, n.2, p.255-260, 1988.

MADAN, M.; VASUDEVAN, P.; SHARMA, S. Cultivation of Pleurotus sajor-caju on different wastes. Biological Wastes, v.22, n.3, p.241-250, 1987.

MALLESHA, B.C.; SHIVAPPASHETTY, K. A new brown spot disease of oyster mushroom caused by Pseudomonas stutzeri. Current Science, v.57, n.21, p.1190-1192, 1988. 
MANSUR, M.; KLIBANSKY, M.; GUTIÉRREZ, I.; GONZÁLES, L. Evaluacion de parametros de processo para la produción de hongos del gênero Pleurotus cultivados sobre paja de cana. Boletim GEPLACEA, v.9, n.8, p.11-21, 1992.

MANZI, P.; GAMBELLI, L.; MARCONI, S.; VIVANTI, V.; PIZZOFERRATO, L. Nutrients in edible mushrooms: an inter-species comparative study. Food Chemistry, v.65, n.4, p.477-482, 1999.

MAZIERO, R.; BONONI, V.L.; CAPELARI, M. Cultivo e produtividade de Pleurotus ostreatus var. "Flórida" em Mogi das Cruzes, S.P., Brasil. Hoehnea, v.19, n.1-2, p.1-7, 1992.

McGUIRE, R.G. Reporting of objective color measurements. HortScience, v.27, n.12, p.1254-1255, 1992.

MORAES, C. Efeito do ácido cítrico e metabissulfito de sódio na qualidade do camarão mantido em gelo de refrigeração. Coletânea do Instituto de Tecnologia de Alimentos, v.25, n.1, p.35-45, 1995.

NARDIM, M.S. Conservação de cogumelos comestíveis ( $P$. sajor-caju) por acidificação e processamento térmico e por desidratação. Piracicaba, 1999. 134p. Dissertação (Mestrado) - Escola Superior de Agricultura "Luiz de Queiroz", Universidade de São Paulo.

ORTEGA, G.M.; MARTINEZ, E.O.; BETANCOURT, D.; GONZALÉZ, A.E.; OTERO, M.A. Bioconversion of sugar cane crop residues with white-rot fungi Pleurotus sp. World Journal of Microbiology and Biotechnology, v.8, n.4, p.402-405, 1992. 
PASCHOLATTI, S.F.; STANGARLIN, J.R.; PICCININ, E. Cogumelos - cultivo e comercialização: shiitake e cogumelo do sol. Cuiabá: SEBRAE - M.T., 1998. 85p. (Coleção Agroindústria)

PATRABANSH, S.; MADAN, M. Studies on cultivation, biological efficiency and chemical analisys of Pleurotus sajor-caju (Fr.) Singer on different biowastes. Acta Biotechnologica, v.17, n.2, p.107-122, 1997.

PEIL, R.M.; ROSSETTO, E.A.; ROCHA, M.T.R. Rendimento do cogumelo Agaricus bisporus (Lang) Imbach em três formulações de compostos. Revista Brasileira de Agrociência, v.1, n.3, p.163-166, 1995.

PERALA-SANTOLARIA, J.M. Setas. Madrid, 1964. 109p. (Série Spain Servicio de Extension Agrária. Série técnica,10)

PERMANA, I.G.; FLACHOWSKY, G.; MEULEN, U. ter; ZADRAZIL, F. Use of sugarcane bagasse for mushroom and animal feed production. Mushroom Science, v.15, part I, p.385-390, 2000.

POPPE, J. Use of agricultural waste materials in the cultivation of mushrooms. Mushroom Science, v.15, part I, p.3-19, 2000.

RAJARATHNAM, S. Pleurotus mushrooms. Part IA. Morfology, life cicle, taxonomy breeding and cultivation. Critical Reviews in Food Science and Nutrition, v.26, n.2, p.157-223, 1987.

RAJARATHNAM, S.; BANO, Z. Pleurotus mushrooms: Part III. Biotransformations of natural lignocellulosic wastes commercial applications and implications. Critical Reviews in Food Science and Nutrition, v.28, n.1, p.31-113, 1989. 
RAJARATHNAM, S. Biopotentialities of the Basidiomacromycetes. Advances in Applied Microbiology, v.37, p.233-361, 1992.

RAJARATHNAM, S. Biodegradative and biosynthetic capacities of mushrooms. Critical Reviews Biotechnology, v.18, n.2/3, p.91-236, 1998.

RODRIGO, M.; CALVO, C.; SANCHEZ, T.; RODRIGO, C.; MARTINEZ, A. Quality of canned mushrooms acidified with glucana-lactone. International Journal of Food Science and Technology, v.34, n.2, p.161-166, 1999.

ROY, S.; ANANTHESWARAN, R.C.; BEELMAN, R.B. Fresh mushroom quality as affected by modified atmosphere packaging. Journal of Food Science, v.60, n.2, p.334-340, 1995a .

ROY, S.; ANANTHESWARAN, R.C.; BEELMAN, R.B. Sorbitol increases shelf life of fresh mushrooms stored in conventional packages. Journal of Food Science, v.60, n.6, p.1254-1259, 1995 b.

ROYSE, D.J.; SCHISLER, L.C. Yield and size of Pleurotus ostreatus and Pleurotus sajor-caju as effected by delayed-release nutrient. Applied Microbiology and Biotechnology, v.26, n.2, p.191-194, 1987.

ROYSE, D.J.; FALES, S.L.; KARUNANANDAA, K. Influence of formaldehyde treated soybean and commercial nutrient supplementation on mushroom (Pleurotus sajor-caju) yield and in vitro dry matter digestibility of spent substrate. Applied Microbiology and Biotechnology, v.36, n.3, p.425429, 1991. 
ROYSE, D.J. Recycling of spent shiitake substrate for production of the oyster mushroom Pleurotus sajor-caju. Applied Microbiology and Biotechnology, v.38, n.2, p.179-182, 1992.

SANGITRAO, C.S. High production technology for Oyster mushroom Pleurotus sajor-caju (Fr.) Singer. Mushroom Science, v.15, part II, p.959-962, 2000.

SAPERS, G.M.; MILLER, R.L.; MILLER, F.C.; COOKE, P.H.; CHOI, S. Enzymatic browning control in minimally processed mushrooms. Journal of Food Science, v.59, n.5, p.1042-1047, 1994.

SAPERS, G.M.; MILLER, R.L.; CHOI, S.W.; COOKE, P.H. Structure and composition of mushrooms as affected by hydrogen peroxide wash. Journal of Food Science, v.64, n.5, p.889-892, 1999.

SAPERS, G.M.; MILLER, R.L.; PILIZOTA, V.; KAMP, F. Shelf-life extension of fresh mushrooms (Agaricus bisporus) by application of hydrogen peroxide and browning inhibitors. Journal of Food Science, v.66, n.2, p.362-366, 2001.

SINGH, M.P. Biodegradation of lignocelulosic wastes through cultivation of Pleurotus sajor-caju. Mushroom Science, v.15, part II, p.517-521, 2000.

SINGER, R.; HARRIS, B. Mushrooms and truffles for human consumption and other uses. In: SINGER, R.; HARRIS, B. Mushrooms and truffles: botany, cultivation and utilization. Ciesnmitt: Koeltz Scientific Books, 1987. cap.13, p.273-278: Mushrooms and truffles for human consumption and other uses. 
STAMETS, P. Growing gourmet \& medicinal mushrooms. Berkely: Speed Press, 1993. 554p.

STURION, G.L.; OETTERER, M. Utilização da folha da bananeira como substrato para cultivo de cogumelos comestíveis (Pleurotus spp.). Ciência e Tecnologia de Alimentos, v.15, n.2, p.194-200, 1995.

STURION, G.L.; RANZANI, M.R.T.de C. Produção do cogumelo comestível Pleurotus: opção promissora, especialmente na região do Vale do Ribeira. Piracicaba: ESALQ, DIBD, 1997. 44p. (Série Produtor Rural, 2)

SUBRAMANIAN, C.V. Mushrooms: beaty, diversity, relevance. Current Science, v.69, n.12, p.986-998, 1995.

TANO, K.; ARUL, J.; DOYON, G.; CASTAIGNE, F. Atmospheric composition and quality of fresh mushrooms in modified atmosfhere packages as affected by storage temperature abuse. Journal of Food Science, v.64, n.6, p.1073-1077, 1999.

VILLALBA, L.F.S. Influência da aplicação de ácido giberélico $\left(\mathrm{GA}_{3}\right)$ na conservação pós-colheita de frutos de acerola (Malpighia glabra L.), sob refrigeração e umidade relativa alta. Piracicaba, 1997. 105p. Dissertação (Mestrado) - Escola Superior de Agricultura "Luiz de Queiroz", Universidade de São Paulo.

VIVAR-QUINTANA, A.M.; GONZALEZ-SAN JOSE, M.L.; COLLADOFERNANDEZ, M. Influence of canning process on colour, weight and grade of mushrooms. Food Chemistry, v.66, n.1, p.87-92, 1999. 
YARA, R. Bactéria associada a Pleurotus sp. São Paulo, 2002. 134p. Dissertação (Mestrado) - Instituto de Biociências, Universidade de São Paulo.

WIESCHE, C. in der; WOLTER, M.; ZADRAZIL, F. Activities of ligninolytic enzymes as a means for monitoring the colonization of straw substrate pretreated at different temperatures by Pleurotus ostreatus. Mushroom Science, v.15, part I, p.391-398, 2000.

WIZENTIER, B.; MACHADO, J.O.; ANDRIOLI, J.L. Crescimento do cogumelo comestível Pleurotus sajor-caju em bagaço de cana não esterilizado. Científica, v.24, n.2, p.341-352, 1996.

ZADRAZIL, F. Influence of ammonium nitrate and organic supplements on the yield of Pleurotus sajor-caju (Fr.) Singer. European Journal of Applied Microbiology and Biotechnology, v.9, p.31-35, 1980.

ZANETTI, A.L.; RANAL, M.A. Efeito de diferentes resíduos agroindustriais na miceliação de Pleurotus sp. "Flórida", em Uberlândia, M.G. Pesquisa Agropecuária Brasileira, v.31, n.3, p.215-220, 1996.

ZANETTI, A.L.; RANAL, M.A. Suplementação da cana-de-açúcar com guandú no cultivo de Pleurotus sp. "Flórida". Pesquisa Agropecuária Brasileira, v.32, n.9, p.959-964, 1997. 